\title{
Pesticide residues in agricultural crops (2016-2017)
}

\section{Pozostałości środków ochrony roślin w płodach rolnych (2016-2017)}

\author{
Anna Nowacka*, Agnieszka Hołodyńska-Kulas
}

\section{Summary}

In the years 2016-2017, the Institute of Plant Protection - National Research Institute tested 3019 samples of domestic agricultural products collected from production sites all over the country for pesticide residues as part of official control conducted in Poland. The study included 60 products and 499 compounds. Most of the samples tested were vegetables (44.6\%) and fruits (33.3\%), the others - cereals $(13.2 \%)$, oilseeds $(4.6 \%)$ and legumes (1.9\%), sugar plants $(2.1 \%)$ and spices $(0.3 \%)$. No residues were found in $61.8 \%$ of the samples. Overall, 99 compounds were found in $38.2 \%$ of all samples. Pesticide residues were detected in $55.8 \%$ of fruit samples, $33.5 \%$ of vegetable samples, $14.9 \%$ of cereal samples, $6.9 \%$ of legume seed samples, $39.3 \%$ of rapeseed samples, $25.8 \%$ of sugar plant samples, as well in $77.8 \%$ of spice samples. Pesticide residues were often found in samples of caraway (77.8\%), apples (70.3\%), celeriac (68.1\%), peaches and sweet cherries (63.2\%), dill (61.9\%), currants $(61.0 \%)$, strawberries $(60.4 \%)$, cucumbers $(59.3 \%)$, sour cherries $(59.2 \%)$, carrots $(58.0 \%)$, grapes $(56.4 \%)$, apricots $(55.6 \%)$, parsley roots $(53.6 \%)$, gooseberries $(52.6 \%)$ and pears $(50.0 \%)$. The most frequently found active substances of plant protection products were dithiocarbamates (9.4\%), boscalid (6.7\%), acetamiprid (5.3\%) and chlorpyrifos (4.9\%). The residues of unauthorised plant protection products were found in $9.0 \%$ of the sample, while the $1.9 \%$ of analysed samples were not compliant with the requirements of the maximum residue levels ( MRLs).

Key words: plant protection products residues, fruit, vegetables, cereals, MRL exceedances, unpermitted substances

\section{Streszczenie}

W latach 2016-2017 Instytut Ochrony Roślin - Państwowy Instytut Badawczy w ramach urzędowej kontroli przebadał 3019 próbek krajowych płodów rolnych na obecność pozostałości środków ochrony roślin, pobranych w gospodarstwach produkcyjnych na obszarze całej Polski. Badaniami objęto 499 związków i 60 produktów. Większość badanych próbek stanowiły warzywa (44,6\%) i owoce (33,3\%), pozostałe próbki - zboża $(13,2 \%)$, nasiona oleiste $(4,6 \%)$ i strączkowe $(1,9 \%)$, rośliny cukrodajne $(2,1 \%)$ i przyprawy $(0,3 \%)$. Pozostałości środków ochrony roślin nie stwierdzono w 61,8\% kontrolowanych próbek. Ogółem wykryto 99 substancji, łącznie w 38,2\% badanych próbek. Pozostałości środków ochrony roślin były obecne w 55,8\% próbek owoców, 33,5\% - warzyw, 14,9\% - zbóż, 6,9\% - nasion roślin strączkowych, 39,3\% - nasion oleistych, 25,8\% - roślin cukrodajnych i w 77,8\% próbek przypraw. Wykrywano je głównie w próbkach kminku (77,8\%), jabłek (70,3\%), selera korzeniowego (68,1\%), brzoskwiń i czereśni (63,2\%), kopru (61,9\%), porzeczek (61,0\%), truskawek $(60,4 \%)$, ogórków $(59,3 \%)$, wiśni $(59,2 \%)$, marchwi $(58,0 \%)$, winogron $(56,4 \%)$, moreli $(55,6 \%)$, korzeni pietruszki $(53,6 \%)$, agrestu (52,6\%) i gruszek (50,0\%). Najczęściej wykrywane były ditiokarbaminiany $(9,4 \%)$, boskalid $(6,7 \%)$, acetamipryd $(5,3 \%)$ i chloropiryfos $(4,9 \%)$. Pozostałości środków niedozwolonych stwierdzono w 9,0\% przebadanych próbek, natomiast w 1,9\% próbek pozostałości niezgodne z wymaganiami w zakresie najwyższych dopuszczalnych poziomów (NDP).

Słowa kluczowe: pozostałości środków ochrony roślin, owoce, warzywa, zboża, przekroczenia NDP, substancje niedozwolone

Instytut Ochrony Roślin - Państwowy Instytut Badawczy

Władysława Węgorka 20, 60-318 Poznań

*corresponding author: a.nowacka@iorpib.poznan.pl

ORCID: 0000-0002-0255-5494 


\section{Wstęp / Introduction}

Stosowanie chemicznych środków ochrony roślin może mieć negatywne skutki dla zdrowia ludzi, zwierząt i środowiska. Dla zapewnienia bezpieczeństwa żywności i pasz konieczne jest monitorowanie poziomów pozostałości środków ochrony roślin (ś.o.r.) w żywności i paszach na etapie ich produkcji i sprzedaży. Szeroko zakrojone badania w tym zakresie są realizowane w ramach urzędowych kontroli, mających umocowania prawne na poziomie krajowym i unijnym. Obowiązek prowadzenia badań pozostałości ś.o.r. wynika z prawa krajowego, w szczególności ustawy z dnia 18 grudnia 2003 r. o ochronie roślin (Ustawa 2004) i ustawy z dnia 8 marca 2013 r. o środkach ochrony roślin (Ustawa 2013) oraz przepisów Unii Europejskiej, rozporządzenia Parlamentu Europejskiego i Rady (WE) nr 1107/2009 z dnia 21 października 2009 r. dotyczącego wprowadzania do obrotu środków ochrony roślin i uchylającego dyrektywy Rady 79/117/EWG i 91/414/EWG (Rozporządzenie 2009), dyrektywy Parlamentu Europejskiego i Rady 2009/128/WE z dnia 21 października 2009 r. ustanawiającej ramy wspólnotowego działania na rzecz zrównoważonego stosowania pestycydów (Dyrektywa 2009), rozporządzenia (WE) nr 396/2005 Parlamentu Europejskiego i Rady z dnia 23 lutego 2005 r. w sprawie najwyższych dopuszczalnych poziomów pozostałości pestycydów w żywności i paszy pochodzenia roślinnego i zwierzęcego oraz na ich powierzchni, zmieniającego dyrektywę Rady 91/414/EWG (Rozporządzenie 2005).

Instytut Ochrony Roślin - Państwowy Instytut Badawczy (IOR - PIB) problemem pozostałości ś.o.r. zajmuje się od początku lat 70. XX wieku. Przedstawione w pracy badania, obejmujące lata 2016-2017, wykonano na rzecz urzędowej kontroli, prowadzonej przez Państwową Inspekcję Ochrony Roślin i Nasiennictwa (PIORiN), w ramach programu wieloletniego IOR - PIB na lata 2016-2020 (Uchwała 2015). Miały one na celu ocenę prawidłowości stosowania środków ochrony roślin, czyli sprawdzenie przestrzegania przez producentów płodów rolnych zapisów art. 55 rozporządzenia dotyczącego wprowadzania do obrotu środków ochrony roślin (Rozporządzenie 2009), art. 46 ustawy o środkach ochrony roślin (Ustawa 2013) oraz rozporządzenia $\mathrm{w}$ sprawie najwyższych dopuszczalnych poziomów pozostałości pestycydów w żywności i paszy pochodzenia roślinnego i zwierzęcego oraz na ich powierzchni (Rozporządzenie 2005). Badania miały dostarczać na bieżąco informacje, pozwalające na szybkie identyfikowanie zagrożeń związanych ze stosowaniem środków ochrony roślin na etapie produkcji pierwotnej - przekroczeń najwyższych dopuszczalnych poziomów pozostałości (NDP) i przypadków nielegalnego stosowania preparatów. Miały one służyć zapobieżeniu wprowadzenia do obrotu produktów niebezpiecznych dla zdrowia ludzi i egzekwowaniu zasad dobrej praktyki rolniczej.

\section{Materiały i metody / Materials and methods}

W latach 2016-2017, w trzech laboratoriach IOR - PIB (Poznań, Białystok, Sośnicowice) w ramach urzędowej kontroli produkcji pierwotnej wykonano badania pozostałości ś.o.r. w próbkach płodów rolnych z rodzimych gospodarstw produkcyjnych. Próbki do badań pobierali na obszarze całej Polski inspektorzy Państwowej Inspekcji Ochrony Roślin i Nasiennictwa zgodnie z harmonogramem opracowanym przez Główny Inspektorat Ochrony Roślin i Nasiennictwa (GIORiN), w sposób określony w rozporządzeniu Ministerstwa Rolnictwa i Rozwoju Wsi (Rozporządzenie 2013). Wyniki badań były niezwłocznie przekazywane w formie sprawozdań właściwym inspektoratom wojewódzkim. Przekroczenia NDP były także sygnalizowane w formie powiadomień RASFF (Rapid Alert System for Food and Feed), zgodnie z rozporządzeniem (WE) ustanawiającym ogólne zasady i wymagania prawa żywnościowego (Rozporządzenie 2002), rozporządzeniem Komisji Unii Europejskiej ustanawiającym środki wykonawcze dla systemu wczesnego ostrzegania o niebezpiecznych produktach żywnościowych i środkach żywienia zwierząt (Rozporządzenie 2011a) oraz ustawą o bezpieczeństwie żywności i żywienia (Ustawa 2010).

Do badań pobrano łącznie 3019 próbek z 60 gatunków roślin uprawnych, w tym 1348 próbek 31 gatunków warzyw (44,6\%), 1005 próbek 14 gatunków owoców $(33,3 \%)$, 397 próbek 9 gatunków zbóż (13,2\%), 140 próbek 2 gatunków nasion oleistych (4,6\%), 58 próbek 2 gatunków jadalnych nasion roślin strączkowych $(1,9 \%), 9$ próbek 1 gatunku przypraw $(0,3 \%)$ i 62 próbki 1 gatunku roślin cukrodajnych $(2,1 \%)$. Do najliczniej reprezentowanych płodów rolnych (> 100 próbek) należały jabłka, truskawki, pomidory, maliny, nasiona rzepaku i porzeczki. W analizowanych próbkach ogółem poszukiwano 499 substancji czynnych ś.o.r. i/lub ich pochodnych, 197 z grupy insektycydów, akarycydów, moluskocydów, nematocydów i rodentycydów, 116 fungicydów, $185 \mathrm{z}$ grupy herbicydów i regulatorów wzrostu roślin oraz 1 biocyd. Dane o liczbie i rodzaju badanych próbek przedstawiono w tabeli 1., a listę oznaczanych związków w tabeli 2.

Do oznaczeń wykorzystano metody ilościowe, głównie wielopozostałościowe, wykorzystujące technikę QuEChERS (Anastassiades i wsp. 2003; Norma 2008; Walorczyk 2008; Walorczyk i Drożdżyński 2011). Do ekstrakcji pozostałości z matrycy używano rozpuszczalniki organiczne, a do oczyszczania ekstraktów technikę dyspersyjnej ekstrakcji do fazy stałej (dSPE - dispersive solid-phase extraction). Pozostałości analizowano metodami chromatografii gazowej i cieczowej sprzężonej z tandemową kwadrupolową spektrometrią mas (GC-MS/MS, LC-MS/MS), jak również chromatografii gazowej z detektorami wychwytu elektronów i termojonowym (GC-ECD/NPD). Do badań ditiokarbaminianów, oznaczanych jako $\mathrm{CS}_{2}$, zastosowano me- 
Tabela 1. Badane produkty

Table 1. Analysed products

\begin{tabular}{|c|c|c|c|}
\hline \multirow{2}{*}{ Produkt ${ }^{1}$ - Product } & \multirow{2}{*}{$\begin{array}{c}\text { Liczba próbek } \\
\text { Number of samples }\end{array}$} & \multicolumn{2}{|c|}{$\%$ próbek - Percentage of samples } \\
\hline & & $\mathrm{A}^{2}$ & $\mathrm{~B}^{3}$ \\
\hline 1 & 2 & 3 & 4 \\
\hline Owoce - Fruits & 1005 & 33,3 & - \\
\hline \multicolumn{4}{|c|}{ Owoce ziarnkowe - Pome fruits } \\
\hline Gruszki - Pears & 70 & 2,3 & 25,1 \\
\hline Jabłka - Apples & 209 & 6,9 & 74,9 \\
\hline \multicolumn{4}{|c|}{ Owoce pestkowe - Stone fruits } \\
\hline Brzoskwinie - Peaches & 19 & 0,6 & 8,8 \\
\hline Czereśnie - Sweet cherries & 38 & 1,2 & 17,7 \\
\hline Morele - Apricots & 9 & 0,3 & 4,2 \\
\hline Śliwki - Plums & 78 & 2,6 & 36,3 \\
\hline Wiśnie - Sour cherries & 71 & 2,3 & 33,0 \\
\hline \multicolumn{4}{|c|}{ Owoce jagodowe - Berries } \\
\hline Agrest - Gooseberries & 38 & 1,3 & 7,8 \\
\hline Maliny - Raspberries & 131 & 4,3 & 27,0 \\
\hline Porzeczki - Currants & 123 & 4,1 & 25,3 \\
\hline Truskawki - Strawberries & 139 & 4,6 & 28,6 \\
\hline Winogrona - Grapes & 55 & 1,8 & 11,3 \\
\hline \multicolumn{4}{|c|}{ Orzechy z drzew orzechowych - Tree nuts } \\
\hline Orzechy laskowe - Hazelnuts & 15 & 0,5 & 60,0 \\
\hline Orzechy włoskie - Walnuts & 10 & 0,3 & 40,0 \\
\hline Warzywa - Vegetables & 1348 & 44,6 & - \\
\hline \multicolumn{4}{|c|}{ Warzywa korzeniowe i bulwiaste - Root and tuber vegetables } \\
\hline Buraki ćwikłowe - Beetroots & 18 & 0,6 & 5,1 \\
\hline Chrzan - Horseradishes & 26 & 0,9 & 7,3 \\
\hline Marchew - Carrots & 69 & 2,3 & 19,4 \\
\hline Pasternak - Parsnips & 15 & 0,5 & 4,2 \\
\hline Pietruszka korzeń - Parsley root & 69 & 2,3 & 19,4 \\
\hline Rzodkiewka - Radish & 46 & 1,5 & 13,0 \\
\hline Seler korzeniowy - Celeriac & 72 & 2,4 & 20,3 \\
\hline Ziemniaki - Potatoes & 40 & 1,3 & 11,3 \\
\hline \multicolumn{4}{|c|}{ Warzywa cebulowe - Bulb vegetables } \\
\hline Cebula-Onion & 48 & 1,6 & 77,4 \\
\hline $\begin{array}{l}\text { Dymka/cebula siedmiolatka i szczypiorowa - Spring onions/green onions } \\
\text { and welsh onions }\end{array}$ & 14 & 0,5 & 22,6 \\
\hline \multicolumn{4}{|c|}{ Warzywa owocowe - Fruiting vegetables } \\
\hline Cukinia - Courgette & 9 & 0,3 & 3,9 \\
\hline Ogórki - Cucumbers & 54 & 1,8 & 23,5 \\
\hline Papryka - Sweet pepper & 30 & 1,0 & 13,0 \\
\hline Pomidory - Tomatoes & 137 & 4,5 & 59,6 \\
\hline \multicolumn{4}{|c|}{ Warzywa kapustne - Brassica vegetables } \\
\hline Brokuły - Broccoli & 61 & 2,0 & 20,3 \\
\hline Jarmuż - Kales & 8 & 0,3 & 2,7 \\
\hline Kalafior - Cauliflower & 38 & 1,3 & 12,6 \\
\hline Kapusta głowiasta - Head cabbage & 69 & 2,3 & 22,9 \\
\hline
\end{tabular}


Tabela 1. Badane produkty $-\mathrm{cd}$.

Table 1. Analysed products - continued

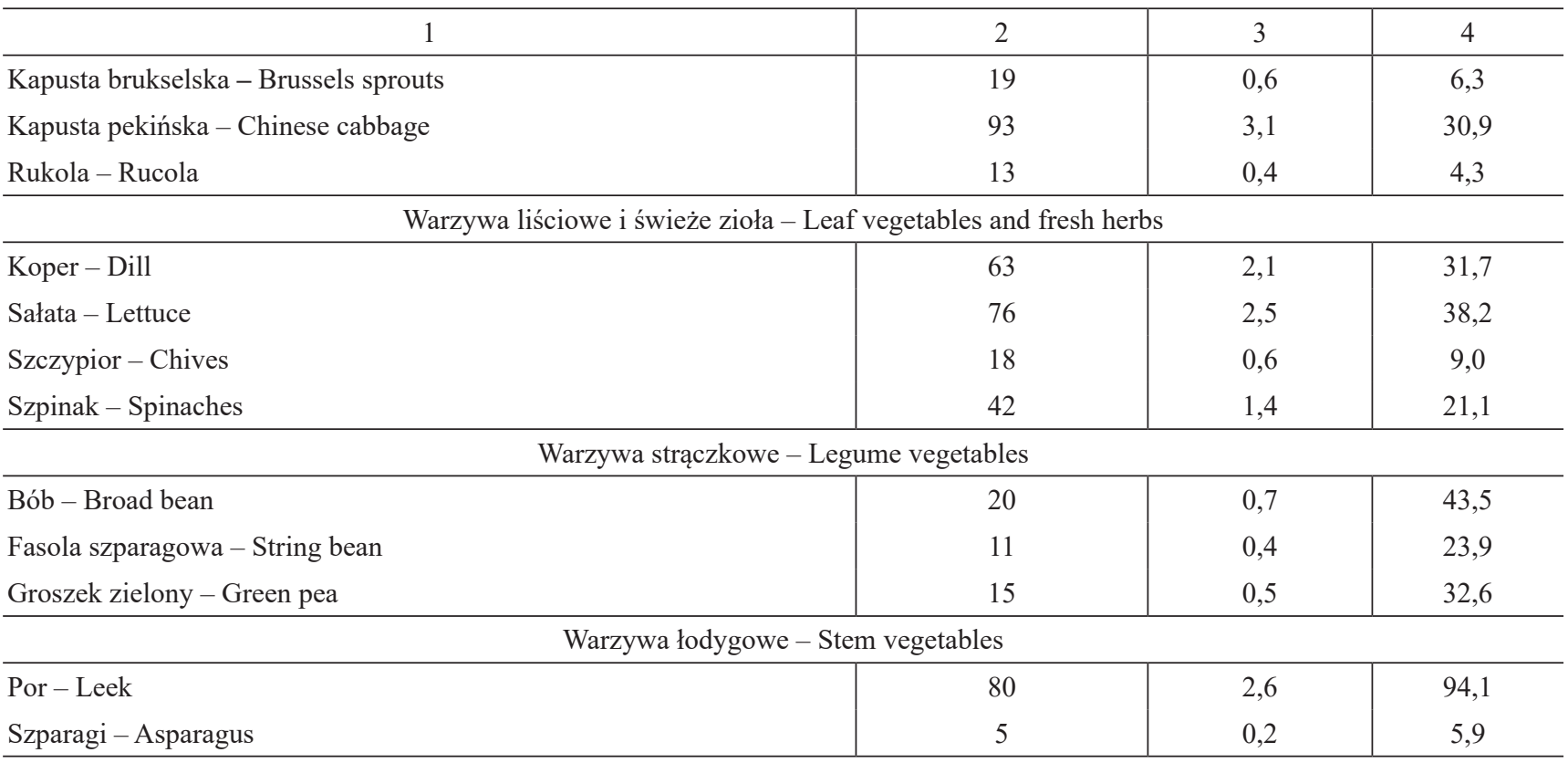

\begin{tabular}{|c|c|c|c|}
\hline Szparagi - Asparagus & 5 & 0,2 & 5,9 \\
\hline \multicolumn{4}{|c|}{ Grzyby uprawne - Cultivated fungi } \\
\hline Pieczarki/Boczniaki - Mushrooms/Oyster mushrooms & 70 & 2,3 & 100,0 \\
\hline Jadalne nasiona roślin strączkowych - Pulses & 58 & 1,9 & - \\
\hline Fasola - Bean & 32 & 1,1 & 55,2 \\
\hline Groch - Pea & 26 & 0,9 & 44,8 \\
\hline Nasiona oleiste - Oilseeds & 140 & 4,6 & - \\
\hline Rzepak - Rapeseed & 130 & 4,3 & 92,9 \\
\hline Soja - Soya bean & 10 & 0,3 & 7,1 \\
\hline Zboża-Cereals & 397 & 13,2 & - \\
\hline Gryka-Buckwheat & 21 & 0,7 & 5,3 \\
\hline Jęczmień - Barley & 27 & 0,9 & 6,8 \\
\hline Kukurydza - Corn & 48 & 1,6 & 12,1 \\
\hline Mieszanka zbożowa - Cereal mix & 48 & 1,6 & 12,1 \\
\hline Owies - Oat & 27 & 0,9 & 6,8 \\
\hline Proso - Common millet & 9 & 0,3 & 2,3 \\
\hline Pszenica - Wheat & 66 & 2,2 & 16,6 \\
\hline Pszenżyto - Triticale & 89 & 2,9 & 22,4 \\
\hline Żyto - Rye & 62 & 2,0 & 15,6 \\
\hline Rośliny cukrodajne - Sugar plants & 62 & 2,1 & - \\
\hline Burak cukrowy - Sugar beet root & 62 & 2,0 & 100,0 \\
\hline Przyprawy - Spices & 9 & 0,3 & - \\
\hline Kminek - Black caraway & 9 & 0,3 & 100,0 \\
\hline
\end{tabular}

${ }^{1}$ klasyfikacja produktów według Rozporządzenia (WE) 396/2005 - classification of products according to Regulation (EC) 396/2005

${ }^{2}$ procent całkowitej liczby badanych próbek - percentage of the total number of samples tested

${ }^{3}$ procent badanych próbek w danej grupie produktów - percentage of samples tested in individual product group

todę spektrofotometryczną (Chmiel 1979). Metody badawcze były akredytowane na zgodność z normą PN-EN ISO/ IEC 17025:2005 przez Polskie Centrum Akredytacji (Norma 2005) i spełniały unijne wymagania w sprawie walida- cji metod oraz kontroli jakości w analizie żywności i pasz (Guidance 2015). Laboratoria prowadzące badania pozostałości ś.o.r. potwierdziły kompetencje w 6 obligatoryjnych międzynarodowych badaniach biegłości przeprowadzonych 
Tabela 2. Poszukiwane związki

Table 2. Analysed compounds

\begin{tabular}{|c|c|c|c|c|c|}
\hline 1 & 2 & 1 & 2 & 1 & 2 \\
\hline $2,4,5-\mathrm{T}$ & $\mathrm{HB}$ & Boscalid* & FU & Clorfenac & HB \\
\hline $2,4-\mathrm{D}$ & $\mathrm{HB}, \mathrm{PG}$ & Bromacil & HB & Clothianidin* & IN \\
\hline 2,4-DB & $\mathrm{HB}$ & Bromophos-ethyl & IN & Crimidine & RO \\
\hline 2-phenylphenol & $\mathrm{FU}$ & Bromophos-methyl & $\mathrm{IN}$ & Cyanazine & HB \\
\hline Abamectin (Avermectin) & $\mathrm{AC}, \mathrm{IN}$ & Bromopropylate & $\mathrm{AC}$ & Cyazofamid & FU \\
\hline Acephate & $\mathrm{IN}$ & Bromoxynil & $\mathrm{HB}$ & Cycloxydim & HB \\
\hline Acetamiprid* & $\mathrm{IN}$ & Bromuconazole & $\mathrm{FU}$ & Cycluron & HB \\
\hline Acetochlor & $\mathrm{HB}$ & Bupirimate* & FU & Cyflufenamid* & $\mathrm{FU}$ \\
\hline Acifluorfen & HB & Buprofezin* & $\mathrm{AC}, \mathrm{IN}$ & Cyfluthrin & $\mathrm{IN}, \mathrm{AC}$ \\
\hline Aclonifen & $\mathrm{HB}$ & Butafenacil & $\mathrm{HB}$ & Cymoxanil* & FU \\
\hline Acrinathrin & $\mathrm{AC}$ & Butoxycarboxim & $\mathrm{AC}, \mathrm{IN}$ & Cypermethrin* & $\mathrm{IN}, \mathrm{AC}$ \\
\hline Alachlor & $\mathrm{HB}$ & Buturon & HB & Cyprazine & HB \\
\hline Aldicarb & NE, IN, AC & Cadusafos & $\mathrm{IN}, \mathrm{NE}$ & Cyproconazole* & FU \\
\hline Aldicarb sulfone & NE, IN, AC & Captafol & FU & Cyprodinil* & FU \\
\hline Aldicarb sulfoxide & NE, IN, AC & Captan* & $\mathrm{FU}$ & Dalapon & $\mathrm{HB}$ \\
\hline Aldrin & IN & Carbaryl & IN, PG & Daminozide & PG \\
\hline alpha-Cypermetrin & IN & Carbendazim* & FU & Dazomet & FU, NE, IN \\
\hline alpha-Endosulfan & $\mathrm{IN}, \mathrm{AC}$ & Carbetamide & HB & DDT (p,p'-DDD, p,p'-DDE, & $\mathrm{IN}$ \\
\hline alpha-HCH & $\mathrm{IN}$ & Carbofuran & IN, NE, AC & o,p'-DDT, p,p'-DDT) & IN \\
\hline Ametoctradin & $\mathrm{FU}$ & Carbofuran-3-hydroxy & IN, NE, AC & DEET & $\mathrm{BC}, \mathrm{RE}$ \\
\hline Ametryn & $\mathrm{HB}$ & Carbosulfan & IN, NE & delta-HCH & $\mathrm{IN}$ \\
\hline Amidosulfuron & $\mathrm{HB}$ & Carboxin* & $\mathrm{FU}$ & Deltamethrin* & IN \\
\hline Aminocarb & $\mathrm{IN}$ & Carfentrazone-ethyl & HB & Demeton-O-sulfoxide & $\mathrm{IN}$ \\
\hline Aminopyralid & HB & Chloramben & $\mathrm{HB}$ & Demeton-S & $\mathrm{IN}$ \\
\hline Amitraz & $\mathrm{IN}, \mathrm{AC}$ & Chlorantraniliprole* & IN & Demeton-S-methyl & $\mathrm{IN}, \mathrm{AC}$ \\
\hline Amitrole & $\mathrm{HB}$ & Chlorbromuron & $\mathrm{HB}$ & Demeton-S-methylsulfone & $\mathrm{IN}$ \\
\hline AMPA & $\mathrm{HB}$ & Chlorfenapyr & $\mathrm{IN}, \mathrm{AC}$ & Desmedipham* & HB \\
\hline Atrazine & $\mathrm{HB}$ & Chlorfenvinphos & $\mathrm{IN}$ & Diafenthiuron & $\mathrm{IN}, \mathrm{AC}$ \\
\hline Azaconazole & $\mathrm{FU}$ & Chlorfluazuron & IN & Diazinon & $\mathrm{IN}, \mathrm{AC}$ \\
\hline Azinphos-ethyl & $\mathrm{IN}, \mathrm{AC}$ & Chloridazon & $\mathrm{HB}$ & Dicamba & HB \\
\hline Azinphos-methyl & $\mathrm{IN}, \mathrm{AC}$ & Chlormequat & PG & Dichlobenil & $\mathrm{HB}$ \\
\hline Azoxystrobin* & FU & Chlorobenzilate & $\mathrm{AC}$ & Dichlofluanid & FU \\
\hline Beflubutamid & $\mathrm{HB}$ & Chlorothalonil* & FU & Dichlorprop & $\mathrm{HB}$ \\
\hline Benalaxyl & FU & Chlorotoluron & HB & Dichlorvos & $\mathrm{IN}, \mathrm{AC}$ \\
\hline Bendiocarb & $\mathrm{IN}$ & Chloroxuron & $\mathrm{HB}$ & Diclobutrazol & $\mathrm{FU}$ \\
\hline Benfuracarb & IN, NE & Chlorpropham & $\mathrm{PG}, \mathrm{HB}$ & Diclofop & $\mathrm{HB}$ \\
\hline Bensulfuron-methyl & $\mathrm{HB}$ & Chlorpyrifos* & $\mathrm{IN}, \mathrm{AC}$ & Diclofop-methyl & $\mathrm{HB}$ \\
\hline Bentazone & $\mathrm{HB}$ & Chlorpyrifos-methyl & $\mathrm{IN}, \mathrm{AC}$ & Dicloran & $\mathrm{FU}$ \\
\hline Benthiavalicarb isopropyl* & FU & Chlorsulfuron & $\mathrm{HB}$ & Dicofol & $\mathrm{AC}$ \\
\hline Benzoximate & $\mathrm{AC}$ & Chlozolinate & $\mathrm{FU}$ & Dicrotophos & $\mathrm{IN}, \mathrm{AC}$ \\
\hline Beta-cyfluthrin & $\mathrm{IN}$ & Chromafenozide & IN & Dieldrin & IN \\
\hline beta-Endosulfan & $\mathrm{IN}, \mathrm{AC}$ & Cinosulfuron & HB & Diethofencarb & $\mathrm{FU}$ \\
\hline beta-HCH & $\mathrm{IN}$ & cis-Chlordane & $\mathrm{IN}$ & Difenoconazole* & $\mathrm{FU}$ \\
\hline Bifenazate & $\mathrm{AC}$ & Clethodim & $\mathrm{HB}$ & Difenoxuron & HB \\
\hline Bifenox & $\mathrm{HB}$ & Clodinafop-propargyl & HB & Difenzoquat & $\mathrm{HB}$ \\
\hline Bifenthrin* & $\mathrm{IN}, \mathrm{AC}$ & Clofentezine & $\mathrm{AC}$ & Diflubenzuron* & IN \\
\hline Bitertanol & $\mathrm{FU}$ & Clomazone* & HB & Diflufenican & HB \\
\hline Bixafen & FU & Clopyralid & $\mathrm{HB}$ & Diflufenzopyr & $\mathrm{HB}$ \\
\hline
\end{tabular}


Tabela 2. Poszukiwane związki - cd.

Table 2. Analysed compounds - continued

\begin{tabular}{|c|c|c|c|c|c|}
\hline & & & \\
\hline 1 & 2 & 1 & 2 & 1 & 2 \\
\hline Dimefuron & $\mathrm{HB}$ & Fenfuram & FU & Foramsulfuron & HB \\
\hline Dimethachlor & HB & Fenhexamid* & FU & Forchlorfenuron & PG \\
\hline Dimethenamid & $\mathrm{HB}$ & Fenitrothion & $\mathrm{IN}, \mathrm{AC}$ & Formetanate & $\mathrm{IN}, \mathrm{AC}$ \\
\hline Dimethoate* & $\mathrm{IN}, \mathrm{AC}$ & Fenobucarb & IN & Formothion & $\mathrm{IN}, \mathrm{AC}$ \\
\hline Dimethomorph* & FU & Fenoprop & PG, HB & Fosetyl & FU \\
\hline Dimoxystrobin & FU & Fenoxaprop & $\mathrm{HB}$ & Fosthiazate & $\mathrm{NE}$ \\
\hline Diniconazole & FU & Fenoxaprop-P & $\mathrm{HB}$ & Fuberidazole & FU \\
\hline Dinotefuran & $\mathrm{IN}$ & Fenoxaprop-P-ethyl & $\mathrm{HB}$ & Furalaxyl & $\mathrm{IN}$ \\
\hline Dioxacarb & IN & Fenoxycarb & IN & Furathiocarb & IN \\
\hline Diphenylamine & PG & Fenpropathrin & $\mathrm{IN}, \mathrm{AC}$ & gamma-HCH (Lindane) & $\mathrm{IN}$ \\
\hline Diquat & $\mathrm{HB}, \mathrm{DE}$ & Fenpropidin* & $\mathrm{FU}$ & Glufosinate & $\mathrm{HB}$ \\
\hline Disulfoton & $\mathrm{IN}$ & Fenpropimorph* & FU & Glyphosate* & $\mathrm{HB}$ \\
\hline Disulfoton sulfone & IN & Fenpyrazamine* & FU & Halofenozide & IN \\
\hline Disulfoton sulfoxide & IN & Fenpyroximate* & $\mathrm{AC}$ & Halosulfuron-methyl & HB \\
\hline \multirow{3}{*}{$\begin{array}{l}\text { Dithiocarbamates }^{1} \\
\text { (mancozeb, maneb, } \\
\text { methiram, propineb, } \\
\text { thiram, ziram)* }\end{array}$} & \multirow{3}{*}{ FU } & Fenthion & $\mathrm{IN}$ & Haloxyfop & $\mathrm{HB}$ \\
\hline & & Fenuron & HB & Haloxyfop-ethoxyethyl & $\mathrm{HB}$ \\
\hline & & Fenvalerate* & $\mathrm{IN}, \mathrm{AC}$ & Haloxyfop-methyl & FU \\
\hline Diuron & $\mathrm{HB}$ & Fipronil & IN & Heptachlor & $\mathrm{IN}$ \\
\hline Dodemorph & FU & Flazasulfuron & $\mathrm{HB}$ & Heptachlor endo-epoxide & $\mathrm{IN}$ \\
\hline Dodine* & $\mathrm{FU}$ & Flonicamid* & $\mathrm{IN}$ & Heptachlor exo-epoxide & IN \\
\hline Emamectin & $\mathrm{IN}$ & Florasulam & $\mathrm{HB}$ & Heptenophos & IN \\
\hline Endosulfan-sulfate & $\mathrm{IN}, \mathrm{AC}$ & Fluazifop* & HB & Hexachlorobenzene (HCB) & $\mathrm{FU}$ \\
\hline Endrin & $\mathrm{IN}$ & Fluazifop-P-butyl & $\mathrm{HB}$ & Hexaconazole & $\mathrm{FU}$ \\
\hline EPN & $\mathrm{IN}, \mathrm{AC}$ & Fluazinam & FU & Hexaflumuron & IN \\
\hline Epoxiconazole* & $\mathrm{FU}$ & Flubendiamide & $\mathrm{IN}$ & Hexazinone & $\mathrm{HB}$ \\
\hline Esfenvalerate & IN & Fludioxonil* & $\mathrm{FU}$ & Hexythiazox* & $\mathrm{AC}, \mathrm{IN}$ \\
\hline Etaconazole & $\mathrm{FU}$ & Flufenacet* & $\mathrm{HB}$ & Hydramethylnon & IN \\
\hline Ethametsulfuron-methyl & $\mathrm{HB}$ & Flufenoxuron & $\mathrm{IN}$ & Imazalil & $\mathrm{FU}$ \\
\hline Ethephon & PG & Flumetralin & PG & Imazamox & $\mathrm{HB}$ \\
\hline Ethiofencarb & $\mathrm{IN}$ & Flumioxazin & $\mathrm{HB}$ & Imazethapyr & HB, PG \\
\hline Ethiofencarb sulfone & $\mathrm{IN}$ & Fluometuron & $\mathrm{HB}$ & Imibenconazole & FU \\
\hline Ethiofencarb sulfoxide & $\mathrm{IN}$ & Fluopicolide* & FU & Imidacloprid* & $\mathrm{IN}$ \\
\hline Ethion & $\mathrm{IN}, \mathrm{AC}$ & Fluopyram* & $\mathrm{FU}$ & Indoxacarb* & $\mathrm{IN}$ \\
\hline Ethiprole & $\mathrm{IN}$ & Fluoroglycofene-ethyl & $\mathrm{HB}$ & Iodosulfuron-methyl & $\mathrm{HB}$ \\
\hline Ethirimol* & $\mathrm{FU}$ & Fluoxastrobin & $\mathrm{FU}$ & Ioxynil & $\mathrm{HB}$ \\
\hline Ethofumesate* & $\mathrm{HB}$ & Fluquinconazole & FU & Ipconazole & $\mathrm{FU}$ \\
\hline Ethoprophos & NE, IN & Fluridone & $\mathrm{HB}$ & Iprodione* & FU, NE \\
\hline Ethoxysulfuron & $\mathrm{HB}$ & Flurochloridone* & $\mathrm{HB}$ & Iprovalicarb* $^{*}$ & $\mathrm{FU}$ \\
\hline Etofenprox* & IN & Fluroxypyr & $\mathrm{HB}$ & Isocarbophos & $\mathrm{IN}$ \\
\hline Etoxazole & IN & Fluroxypyr-meptyl & $\mathrm{HB}$ & Isofenphos & $\mathrm{IN}$ \\
\hline Famoxadon* & $\mathrm{FU}$ & Flurtamone & $\mathrm{HB}$ & Isofenphos-methyl & $\mathrm{IN}$ \\
\hline Fenamidone* & FU & Flusilazole & $\mathrm{FU}$ & Isoprocarb & $\mathrm{IN}$ \\
\hline Fenamiphos & $\mathrm{NE}$ & Fluthiacet-methyl & $\mathrm{HB}$ & Isoprothiolane & $\mathrm{FU}$ \\
\hline Fenarimol & FU & Flutolanil & FU & Isoproturon & $\mathrm{HB}$ \\
\hline Fenazaquin* & $\mathrm{AC}$ & Flutriafol* & FU & Isopyrazam & FU \\
\hline Fenbuconazole* & FU & Fluxapyroxad & FU & Isoxaben & $\mathrm{HB}$ \\
\hline Fenbutatin oxide & $\mathrm{AC}$ & Folpet* & $\mathrm{FU}$ & Isoxaflutole & $\mathrm{HB}$ \\
\hline Fenchlorophos & IN & Fonofos & IN & Kresoxim-methyl* & $\mathrm{FU}$ \\
\hline
\end{tabular}


Tabela 2. Poszukiwane związki - cd.

Table 2. Analysed compounds - continued

\begin{tabular}{|c|c|c|c|c|c|}
\hline 1 & 2 & 1 & 2 & 1 & 2 \\
\hline Lambda-Cyhalothrin* & IN & Monolinuron & HB & Primisulfuron-methyl & HB \\
\hline Lenacil & $\mathrm{HB}$ & Monuron & HB & Prochloraz* & $\mathrm{FU}$ \\
\hline Linuron* & HB & Myclobutanil & FU & Procyazine & $\mathrm{HB}$ \\
\hline Lufenuron & $\mathrm{IN}$ & Naled & $\mathrm{IN}, \mathrm{AC}$ & Procymidone & $\mathrm{FU}$ \\
\hline Malaoxon & $\mathrm{IN}, \mathrm{AC}$ & Napropamide & $\mathrm{HB}$ & Profenofos & $\mathrm{IN}$ \\
\hline Malathion & $\mathrm{IN}, \mathrm{AC}$ & Neburon & HB & Profoxydim & $\mathrm{HB}$ \\
\hline Maleic hydrazide & PG & Nicosulfuron & HB & Promecarb & IN \\
\hline Mandipropamid* & $\mathrm{FU}$ & Nitenpyram & IN & Prometon & $\mathrm{HB}$ \\
\hline МСРА & HB & Nitrofen & HB & Prometryn* & $\mathrm{HB}$ \\
\hline $\mathrm{MCPB}$ & $\mathrm{HB}$ & Norflurazon & HB & Propachlor & $\mathrm{HB}$ \\
\hline Mecarbam & IN, AC & Novaluron & IN & Propamocarb* & $\mathrm{FU}$ \\
\hline Mecoprop & $\mathrm{HB}$ & Omethoate* & $\mathrm{IN}, \mathrm{AC}$ & Propaquizafop & HB \\
\hline Mefenacet & HB & Oxadixyl & $\mathrm{FU}$ & Propargite* & $\mathrm{AC}$ \\
\hline Mepanipyrim* & FU & Oxamyl & IN, NE & Propazine & $\mathrm{HB}$ \\
\hline Mepiquat* & PG & Oxamyl-oxime & IN, NE & Propham & HB, PG \\
\hline Mepronil & $\mathrm{FU}$ & Oxycarboxin & $\mathrm{FU}$ & Propiconazole* & FU \\
\hline Mesosulfuron-methyl & HB & Oxydemeton-methyl & $\mathrm{IN}, \mathrm{AC}$ & Propoxur & $\mathrm{IN}$ \\
\hline Mesotrione & HB & Oxyfluorfen & $\mathrm{HB}$ & Propoxycarbazone-sodium & $\mathrm{HB}$ \\
\hline Metaflumizone & IN & Paclobutrazol & PG & Propyzamide* & HB \\
\hline \multirow{2}{*}{$\begin{array}{l}\text { Metalaxyl (sum of metalaxyl } \\
\text { and metalaxyl-M)* }\end{array}$} & \multirow{2}{*}{ FU } & Paraoxon-ethyl & IN, AC & Proquinazid & $\mathrm{FU}$ \\
\hline & & Paraoxon-methyl & IN, RE & Prosulfocarb* & HB \\
\hline Metamitron & HB & $\underline{\text { Paraquat }}$ & $\mathrm{HB}$ & Prosulfuron & HB \\
\hline Metazachlor & HB & Parathion & $\mathrm{IN}, \mathrm{AC}$ & Prothioconazole-desthio & $\mathrm{FU}$ \\
\hline Metconazole & FU, PG & Parathion-methyl & $\mathrm{IN}, \mathrm{RE}$ & Prothiofos & IN \\
\hline Metfuroxam & FU & Penconazole* & FU & Pymetrozine & IN \\
\hline Methabenzthiazuron & $\mathrm{HB}$ & Pencycuron* & $\mathrm{FU}$ & Pyracarbolid & $\mathrm{FU}$ \\
\hline Methacrifos & $\mathrm{IN}$ & Pendimethalin* & $\mathrm{HB}$ & Pyraclostrobin* & FU, PG \\
\hline Methamidophos & IN & Penflufen & FU & Pyraflufen & $\mathrm{HB}$ \\
\hline Methidathion & $\mathrm{IN}, \mathrm{AC}$ & Penoxsulam & $\mathrm{HB}$ & Pyrazophos & FU \\
\hline Methiocarb sulfone & IN, RE & Penthiopyrad & FU & Pyrethrins & IN \\
\hline Methiocarb sulfoxide & IN, RE & Permethrin & IN & Pyridaben* & $\mathrm{AC}, \mathrm{IN}$ \\
\hline Methiocarb* & IN, RE & Pethoxamid & $\mathrm{HB}$ & Pyridafol & $\mathrm{HB}$ \\
\hline Methomyl & IN & Phenmedipham & $\mathrm{HB}$ & Pyridalyl & $\mathrm{IN}$ \\
\hline Methoprotryne & $\mathrm{HB}$ & Phenthoate & IN & Pyridate & $\mathrm{HB}$ \\
\hline Methoxychlor & IN & Phorate & $\mathrm{IN}$ & Pyrimethanil* & $\mathrm{FU}$ \\
\hline Methoxyfenozide* & IN & Phorate sulfone & IN & Pyriproxyfen & $\mathrm{IN}$ \\
\hline Metobromuron* & HB & Phorate sulfoxide & $\mathrm{IN}$ & Pyroxsulam & $\mathrm{HB}$ \\
\hline \multirow{2}{*}{$\begin{array}{l}\text { Metolachlor (sum of } \\
\text { metolachlor and } \\
\text { S-metolachlor) }\end{array}$} & \multirow{2}{*}{$\mathrm{HB}$} & Phosalone & $\mathrm{IN}, \mathrm{AC}$ & Quinalphos & IN \\
\hline & & Phosmet* & IN & Quinmerac & $\mathrm{HB}$ \\
\hline Metolcarb & $\mathrm{IN}$ & Phoxim & IN & Quinoclamine & $\mathrm{HB}$ \\
\hline Metosulam & $\mathrm{HB}$ & Picloram & $\mathrm{HB}$ & Quinoxyfen & $\mathrm{FU}$ \\
\hline Metoxuron & $\mathrm{HB}$ & Picolinafen & $\mathrm{HB}$ & Quintozene & $\mathrm{FU}$ \\
\hline Metrafenone & $\mathrm{FU}$ & Picoxystrobin* & FU & \multirow{2}{*}{$\begin{array}{l}\text { Quizalofop } \\
\text { Quizalofop-P }\end{array}$} & \multirow{2}{*}{$\mathrm{HB}$} \\
\hline Metribuzin* & $\mathrm{HB}$ & Pinoxaden & $\mathrm{HB}$ & & \\
\hline Metsulfuron-methyl & $\mathrm{HB}$ & Pirimicarb desmethyl & IN & Quizalofop-P-ethyl & $\mathrm{HB}$ \\
\hline Mevinphos & $\mathrm{IN}, \mathrm{AC}$ & Pirimicarb* & IN & Resmethrin & IN \\
\hline Mexacarbate & $\mathrm{IN}, \mathrm{AC}, \mathrm{MO}$ & Pirimiphos-ethyl & IN & Rimsulfuron & $\mathrm{HB}$ \\
\hline Monocrotophos & $\mathrm{AC}, \mathrm{IN}$ & Pirimiphos-methyl* & IN & Rotenone & IN \\
\hline
\end{tabular}


Tabela 2. Poszukiwane związki - cd.

Table 2. Analysed compounds - continued

\begin{tabular}{l|c}
\hline \multicolumn{1}{|c|}{1} & 2 \\
\hline Secbumeton & $\mathrm{HB}$ \\
\hline Siduron & $\mathrm{HB}$ \\
\hline Silthiofam & $\mathrm{FU}$ \\
\hline Simazine & $\mathrm{HB}$ \\
\hline Simetryn & $\mathrm{HB}$ \\
\hline Spinosad (sum of spinosyn A & $\mathrm{IN}$ \\
and spinosyn D)* & $\mathrm{AC}$, IN \\
\hline Spirodiclofen* & $\mathrm{AC}, \mathrm{IN}$ \\
\hline Spiromesifen & $\mathrm{IN}$ \\
\hline Spirotetramat* & $\mathrm{FU}$ \\
\hline Spiroxamine* & $\mathrm{HB}$ \\
\hline Sulcotrione & $\mathrm{HB}$ \\
\hline Sulfentrazone & $\mathrm{HB}$ \\
\hline Sulfometuron-methyl & $\mathrm{HB}$ \\
\hline Sulfosulfuron & $\mathrm{IN}, \mathrm{AC}$ \\
\hline Sulfotep & $\mathrm{IN}$ \\
\hline tau-Fluvalinate & $\mathrm{IN}$ \\
\hline Tebuconazole* & $\mathrm{IN}$ \\
\hline Tebufenozide & $\mathrm{AC}$ \\
\hline Tebufenpyrad & $\mathrm{HB}$ \\
\hline Tebuthiuron & $\mathrm{FU}, \mathrm{PG}$ \\
\hline Tecnazene & $\mathrm{IN}$ \\
\hline Teflubenzuron & $\mathrm{IN}$ \\
\hline Tefluthrin & $\mathrm{HB}$ \\
\hline Tembotrione & $\mathrm{HB}$ \\
\hline Tepraloxydim & $\mathrm{IN}$ \\
\hline Terbufos & $\mathrm{HB}$ \\
\hline Terbumeton & \\
\hline Terbuthylazine* & \\
\hline
\end{tabular}

\begin{tabular}{l|c}
\hline \multicolumn{1}{c|}{1} & 2 \\
\hline Terbutryn & $\mathrm{HB}$ \\
\hline Tetrachlorvinphos & $\mathrm{IN}$ \\
\hline Tetraconazole* & $\mathrm{FU}$ \\
\hline Tetradifon & $\mathrm{AC}$, IN \\
\hline Tetramethrin & $\mathrm{IN}$ \\
\hline Thiabendazole & $\mathrm{FU}$ \\
\hline Thiacloprid* & $\mathrm{IN}$ \\
\hline Thiamethoxam* & $\mathrm{IN}$ \\
\hline Thidiazuron & $\mathrm{PG}$ \\
\hline Thifensulfuron-methyl & $\mathrm{HB}$ \\
\hline Thiobencarb & $\mathrm{HB}$ \\
\hline Thiodicarb & $\mathrm{IN}$ \\
\hline Thiofanox sulfone & $\mathrm{IN}$ \\
\hline Thiofanox sulfoxide & $\mathrm{IN}$ \\
\hline Thiophanate-ethyl & $\mathrm{FU}$ \\
\hline Thiophanate-methyl* & $\mathrm{FU}$ \\
\hline Tolclofos-methyl & $\mathrm{FU}$ \\
\hline Tolylfluanid & $\mathrm{FU}, \mathrm{AC}$ \\
\hline Tralkoxydim & $\mathrm{HB}$ \\
\hline trans-Chlordane & $\mathrm{IN}$ \\
\hline Triadimefon & $\mathrm{FU}$ \\
\hline Triadimenol* & $\mathrm{FU}$ \\
\hline Tri-allate & $\mathrm{HB}$ \\
\hline Triasulfuron & $\mathrm{HB}$ \\
\hline Triazophos & $\mathrm{IN}, \mathrm{AC}$ \\
\hline Triazoxide & $\mathrm{FU}$ \\
\hline Tribenuron-methyl & $\mathrm{HB}$ \\
\hline Trichlorfon & \\
\hline & \\
\hline
\end{tabular}

\begin{tabular}{l|c}
\hline \multicolumn{1}{c|}{1} & 2 \\
\hline Triclopyr & $\mathrm{HB}$ \\
\hline Tricyclazole & $\mathrm{FU}$ \\
\hline Trifloxystrobin* & $\mathrm{FU}$ \\
\hline Triflumizole & $\mathrm{FU}$ \\
\hline Triflumuron & $\mathrm{IN}$ \\
\hline Trifluralin* & $\mathrm{HB}$ \\
\hline Triflusulfuron-methyl & $\mathrm{HB}$ \\
\hline Triforine & $\mathrm{FU}, \mathrm{AC}$ \\
\hline Trimethyl-sulfonium & $\mathrm{HB}$ \\
(Trimesium) & $\mathrm{PG}$ \\
\hline Trinexapac & $\mathrm{FU}$ \\
\hline Triticonazole & $\mathrm{HB}$ \\
\hline Tritosulfuron & $\mathrm{PG}$ \\
\hline Uniconazole & $\mathrm{IN}, \mathrm{AC}$ \\
\hline Vamidothion & $\mathrm{FU}$ \\
\hline Vinclozolin & $\mathrm{IN}$ \\
\hline zeta-Cypermethrin & $\mathrm{FU}$ \\
\hline Zoxamide &
\end{tabular}

${ }^{1}$ oznaczane jako pozostałości $\mathrm{CS}_{2}-$ determined as $\mathrm{CS}_{2}$ residues

*związki wykryte - compounds detected

AC - akarycyd - acaricide

DE - desykant - dessicant

FU - fungicyd - fungicide

IN - insektycyd - insecticide

$\mathrm{H}$ - herbicyd - herbicide

$\mathrm{MO}$ - moluskocyd - molluscicide

$\mathrm{NE}$ - nematocyd - nematocide

$\mathrm{PG}$ - regulator wzrostu roślin - plant grow regulator

$\mathrm{RE}$ - repelent - repellent

$\mathrm{RO}$ - rodentycyd - rodencitide

$\mathrm{BC}$ - biocyd - biocide

przez trzy Laboratoria Referencyjne Unii Europejskiej - do spraw warzyw i owoców (EURL-FV), zbóż i pasz (EURL-CF) oraz metod pojedynczych (EURL-SRM) ${ }^{1}$.

${ }^{1}$ EURL-Proficiency Test-FV-18, 2016. Pesticide Residues in Spinach Homogenate. Final Report. EU Reference Laboratory for Pesticide Residues in Fruits and Vegetables (University of Almeria).

EURL-Proficiency Test-FV-19, 2017. Pesticide Residues in Lemon Homogenate. Final Report. EU Reference Laboratory for Pesticide Residues in Fruits and Vegetables (University of Almeria).

EUPT-CF10, 2016. Proficiency Test on pesticide residues in rye flour. Final report. EU Reference Laboratory for Pesticide Residues in Cereals and Feeding stuff (National Food Institute, Technical University of Denmark). EUPT-CF11, 2017. Proficiency Test on pesticide residues in oat flour. Final report. EU Reference Laboratory for Pesticide Residues in Cereals and Feeding stuff (National Food Institute, Technical University of Denmark). EU Proficiency Test SRM11, 2016. Residues of pesticides Requiring Single Residue Methods. Test item: Spinach Homogenate. EU Reference Laboratory for Single Residue Methods (Chemisches und Veterinäruntersuchungsamt (CVUA), Stuttgart).

EUPT-Test SRM12, 2017. EU Proficiency Test on the Analysis of Pesticide Residues Requiring Single Residue Methods in Strawberry Purée Homogenate. EU Reference Laboratory for Single Residue Methods (Chemisches und Veterinäruntersuchungsamt (CVUA), Stuttgart).
Wyniki badań były oceniane pod kątem spełnienia wymagań w zakresie pozostałości ś.o.r. (Rozporządzenie 2005) zgodnie z zasadami podejmowania decyzji określonymi w dokumencie SANTE 11945/2015 (Guidance 2015). Zawartość pozostałości interpretowano jako niezgodną z wymaganiami, gdy przekraczała najwyższy dopuszczalny poziom, po uwzględnieniu 50-procentowej niepewności pomiaru (MU), czyli wtedy, gdy spełniona została nierówność: Poziom Pozostałości - MU > NDP.

\section{Wyniki i dyskusja / Results and discussion}

W 1865 badanych próbkach $(61,8 \%)$ nie wykryto pozostałości ś.o.r. W 1154 próbkach $(38,2 \%)$ stwierdzono ich obecność. Odsetek próbek z jedną pozostałością wynosił $18,1 \%$, natomiast $\mathrm{z}$ wieloma pozostałościami stanowił $20,1 \%$. Pozostałości dwóch substancji wykryto w $8,1 \%$ 
próbek, trzech w 5,9\%, czterech w 2,3\%, pięciu w 2,0\%, a sześciu w $1,0 \%$, a od siedemiu do jedenastu w $0,9 \%$ próbek. Pozostałości ś.o.r. występowały głównie w owocach $(55,8 \%)$ i przyprawach $(77,8 \%)$, nieco rzadziej w nasionach oleistych $(39,3 \%)$, warzywach $(33,5 \%)$ oraz roślinach cukrodajnych (25,8\%), sporadycznie w ziarnie zbóż (14,9\%) i nasionach roślin strączkowych (6,9\%). Częstotliwość ich wykrywania ogółem i w grupach produktów przedstawia rysunek 1., a rozkład procentowy próbek z wieloma pozostałościami rysunek 2.

Od 2,1\% do 77,8\% próbek 56 badanych produktów zawierało pozostałości ś.o.r. (rys. 3). Niski odsetek próbek z pozostałościami stanowiący od $2,1 \%$ do $20,0 \%$ odnotowano dla cebuli, kukurydzy, kapusty głowiastej, kalafiora, nasion fasoli i grochu, szpinaku, żyta, gryki, soi, chrzanu, porów, mieszanek zbożowych, pszenżyta, owsa, bobu, papryki, fasoli szparagowej, brokułów, szparagów i ziemniaków, natomiast mieszczący się w zakresie 21,2-50,0\% dla pszenicy, prosa, rukoli, rzodkiewek, buraków cukrowych, pasternaku, grochu zielonego, szczypiorku, cebuli typu dymka, siedmiolatka, szczypiorowa, a także malin, kapusty brukselskiej, sałaty, jarmużu, kapusty pekińskiej, pieczarek, jęczmienia, nasion rzepaku, pomidorów, śliwek i gruszek. Z częstością oscylującą między 52,6\% a 77,8\% występowały pozostałości w agreście, korzeniach pietruszki, morelach, winogronach, marchwi, wiśniach, ogórkach, truskawkach, porzeczkach, koprze, brzoskwiniach, czereśniach, selerze korzeniowym, jabłkach i kminku. W próbkach buraków ćwikłowych, cukinii oraz orzechów laskowych i włoskich pozostałości ś.o.r. nie stwierdzono.

Ogółem w badanych próbkach wykryto 99 substancji czynnych: 50 fungicydów, 32 substancje należące do grupy insektycydów i akarycydów oraz 17 z grupy herbicydów i regulatorów wzrostu, a częstość ich wykrywania stanowiła od $0,03 \%$ do $17,7 \%$ (rys. 4). Odsetek wykryć w przypadku 74 substancji był niski, dla 24 wynosił zaledwie $0,03 \%$, a dla 50 mieścił się w granicach $0,07-0,7 \%$. Nieco częściej (1,0-2,8\%) stwierdzano pozostałości: metalaksylu, tetrakonazolu, pirymikarbu, propamokarbu, metoksyfenozydu, fenpiroksymatu, pirymetanilu, pirymifosu metylowego, difenokonazolu, trifloksystrobiny, tiofanatu metylowego, tiachloprydu, fluopyramu i linuronu. W głównej mierze wykrywano pozostałości 9 fungicydów - ditiokarbaminianów $(9,4 \%)$, boskalidu $(6,7 \%)$, piraklostrobiny $(3,7 \%)$, azoksystrobiny (3,5\%), tebukonazolu (3,5\%), karbendazymu i fludioksonilu (3,4\%), kaptanu i cyprodynilu $(3,1 \%)$ oraz 2 insektycydów - acetamiprydu $(5,3 \%)$ i chloropiryfosu $(4,9 \%)$. Glifosat wykryto co prawda w $17,7 \%$ próbek, ale był on oznaczany tylko w nasionach rzepaku. Dane statystyczne dotyczące wy-

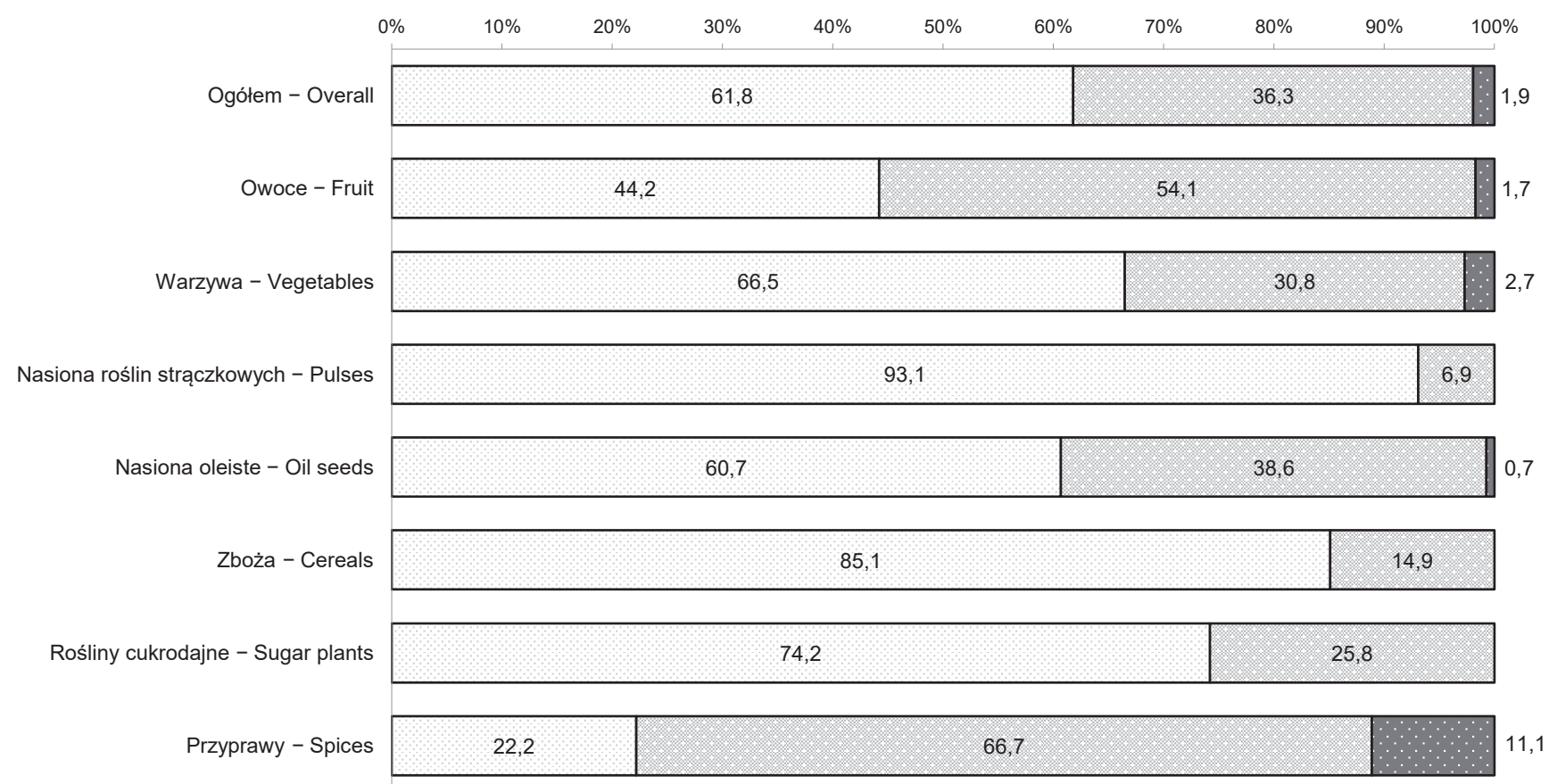

口Próbki bez pozostałości - Samples with no residue

$\square$ Próbki z pozostałościami $\leq$ NDP - Samples with residues $\leq$ MRLs

口Próbki z pozostałościami > NDP - Samples with residues > MRLs

Rys. 1. Odsetek próbek z lub bez pozostałości oraz z pozostałościami przekraczającymi NDP w latach 2026-2017 (ogólny, grupy produktów) Fig. 1. Percentage of samples with and without measurable residues, and residues exceeding the MRLs in 2016-2017 (total, product groups) 


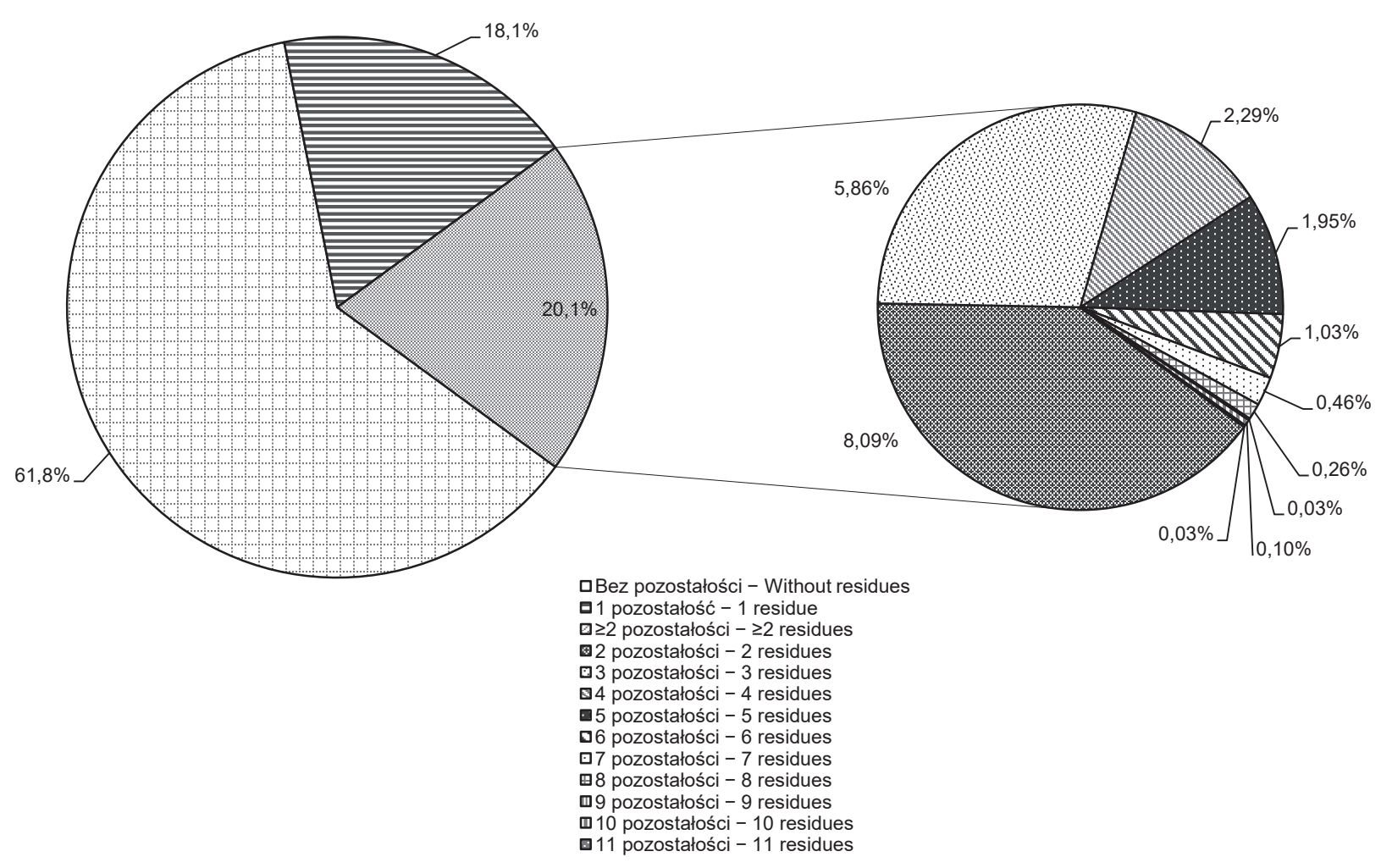

Rys. 2. Odsetek próbek z wieloma pozostałościami (2016-2017)

Fig. 2. The percentage of samples with multiple residues (2016-2017)

krytych związków w poszczególnych produktach podano w tabeli 3.

Występowanie pozostałości $\mathrm{w}$ płodach rolnych było zależne od zakresu stosowanej ochrony, terminów i liczby wykonanych zabiegów, okresów karencji oraz szybkości zanikania substancji czynnych w roślinach uprawnych. Największą różnorodność pozostałości stwierdzono: w jabłkach (36), pomidorach (28), porzeczkach (27), truskawkach (26), agreście (24), gruszkach i sałacie (23), śliwkach, koprze, kapuście pekińskiej (22) oraz w winogronach (20). Kilkanaście związków wykryto w ponad 20,0\% badanych próbek niektórych produktów: 14 fungicydów - azoksystrobinę w selerze korzeniowym (33,3\%), grochu zielonym $(26,7 \%)$, cebuli typu dymka, siedmiolatka, szczypiorowa $(21,4 \%)$; boskalid w truskawkach $(33,1 \%)$; bupirymat w agreście $(26,3 \%)$; cyprodynil w winogronach $(23,6 \%)$ i kminku $(22,2 \%)$; ditiokarbaminiany w porzeczkach $(31,7 \%)$ i szparagach $(20,0 \%)$; fludioksonil w winogronach $(23,6 \%)$ i kminku $(22,2 \%)$; fluopyram w truskawkach $(20,9 \%)$; kaptan w jabłkach $(30,1 \%)$; karbendazym w brzoskwiniach (42,1\%), śliwkach (20,5\%) i winogronach $(20,0 \%)$; metalaksyl w jarmużu $(25,0 \%)$, ogórkach $(22,2 \%)$ i winogronach $(20,0 \%)$; prochloraz w pieczarkach $(31,4 \%)$; propamokarb w ogórkach $(20,4 \%)$; tiofanat metylowy w agreście $(36,8 \%)$ i morelach $(22,2 \%)$ oraz trifloksystrobinę w porzeczkach $(24,4 \%)$; 4 insektycydy - acetamipryd w czereśniach (34,2\%), morelach (33,3\%), wiśniach (26,8\%), jabłkach $(25,4 \%)$ i porzeczkach $(22,0 \%)$; chloropiryfos w kminku (55,6\%), koprze (42,9\%), marchwi $(29,0 \%)$, jarmużu $(25,0 \%)$ i kapuście brukselskiej $(21,1 \%)$; dimetoat w morelach $(22,2 \%)$; pirymifos metylowy w jęczmieniu $(22,2 \%)$ oraz 1 herbicyd - linuron w selerze korzeniowym $(37,5 \%)$, pietruszce $(33,3 \%)$, marchwi $(20,3 \%)$.

W 56 próbkach $(1,9 \%)$ wykryte poziomy pozostałości były niezgodne z wymaganiami (tab. 4), czyli wyższe od NDP (Rozporządzenie 2005), po odjęciu 50-procentowej niepewności pomiaru (Guidance 2015). Ponadnormatywny poziom pozostałości jednego związku wykryto w 52 próbkach, a dwóch związków w 4 próbkach. Naruszenia NDP odnotowano dla 23 substancji czynnych oraz 21 produktów (rys. 3,4 ), wykryto je w $2,7 \%$ próbek warzyw, 1,7\% próbek owoców, $11,1 \%$ próbek przypraw i $0,7 \%$ próbek nasion oleistych. Odsetek próbek z przekroczeniami NDP był wyższy, aniżeli 10-procentowy, w przypadku próbek moreli (22,2\%), kopru (15,9\%), kapusty pekińskiej $(14,0 \%)$ i kminku $(11,1 \%)$. Dla próbek niezgodnych $\mathrm{z}$ wymaganiami wystawiono powiadomienia RASFF, stanowiące dla PIORiN podstawę do podejmowania działań mających na celu zabezpieczenie płodów rolnych mogących zagrażać zdrowiu ludzi, jak również do nakładania sankcji wobec producentów niesprzestrzegających prawa.

Większość przekroczeń NDP $(1,7 \%)$ wynikała z użycia środków niedopuszczonych do ochrony upraw, w szcze- 
Tabela 3. Pozostałości środków ochrony roślin wykryte w poszczególnych produktach Table 3. Pesticide residues detected in individual products

\begin{tabular}{|c|c|c|c|c|c|}
\hline \multirow[t]{2}{*}{$\begin{array}{l}\text { Produkt } \\
\text { Product }\end{array}$} & \multirow[t]{2}{*}{$\begin{array}{c}\text { Związek } \\
\text { Compound }\end{array}$} & \multirow{2}{*}{$\begin{array}{c}\text { Liczba badanych } \\
\text { próbek } \\
\text { Number of } \\
\text { analysed samples }\end{array}$} & \multicolumn{2}{|c|}{$\begin{array}{c}\text { Próbki } \\
\text { z pozostałościami } \\
\text { Samples with } \\
\text { residues }\end{array}$} & \multirow[t]{2}{*}{$\begin{array}{c}\text { Zakres pozostałości } \\
\text { Range of residues } \\
{[\mathrm{mg} / \mathrm{kg}]}\end{array}$} \\
\hline & & & $\begin{array}{l}\text { liczba } \\
\text { number }\end{array}$ & $\begin{array}{c}\text { procent } \\
\text { percentage }\end{array}$ & \\
\hline 1 & 2 & 3 & 4 & 5 & 6 \\
\hline \multicolumn{6}{|c|}{ Owoce - Fruits } \\
\hline \multicolumn{6}{|c|}{ Owoce ziarnkowe - Pome fruits } \\
\hline \multirow{23}{*}{ Gruszki - Pears } & acetamiprid & 70 & 9 & 12,9 & $0,006-0,023$ \\
\hline & boscalid & 70 & 11 & 15,7 & $0,012-0,25$ \\
\hline & captan & 70 & 7 & 10,0 & $0,01-0,18$ \\
\hline & carbendazim & 70 & 4 & 5,7 & $0,01-0,16$ \\
\hline & chlorpyrifos $^{\mathrm{N}}$ & 70 & 1 & 1,4 & 0,024 \\
\hline & clothianidin & 70 & 3 & 4,3 & $0,01-0,015$ \\
\hline & cyprodinil & 70 & 4 & 5,7 & $0,005-0,31$ \\
\hline & difenoconazole & 70 & 3 & 4,3 & $0,006-0,008$ \\
\hline & diflubenzuron & 70 & 6 & 8,6 & $0,01-0,056$ \\
\hline & dithiocarbamates & 70 & 8 & 11,4 & $0,05-0,20$ \\
\hline & dodine & 70 & 2 & 2,9 & $0,02-0,033$ \\
\hline & fludioxonil & 70 & 3 & 4,3 & $0,02-0,17$ \\
\hline & fluopyram & 70 & 4 & 5,7 & $0,04-0,22$ \\
\hline & imidacloprid $^{\mathrm{N}}$ & 70 & 1 & 1,4 & 0,060 \\
\hline & indoxacarb $^{N}$ & 70 & 1 & 1,4 & 0,005 \\
\hline & methoxyfenozide ${ }^{\mathrm{N}}$ & 70 & 2 & 2,9 & $0,009-0,12$ \\
\hline & pyraclostrobin & 70 & 10 & 14,3 & $0,007-0,09$ \\
\hline & tebuconazole & 70 & 8 & 11,4 & $0,005-0,12$ \\
\hline & tetraconazole $\mathrm{N}^{\mathrm{N}}$ & 70 & 1 & 1,4 & 0,015 \\
\hline & thiamethoxam $^{\mathrm{N}}$ & 70 & 1 & 1,4 & 0,008 \\
\hline & thiophanate-methyl & 70 & 3 & 4,3 & $0,042-0,15$ \\
\hline & triadimenol & 70 & 1 & 1,4 & 0,010 \\
\hline & trifloxystrobin & 70 & 1 & 1,4 & 0,007 \\
\hline \multirow{15}{*}{ Jabłka - Apples } & acetamiprid & 209 & 53 & 25,4 & $0,005-0,14$ \\
\hline & boscalid & 209 & 37 & 17,7 & $0,01-0,27$ \\
\hline & bupirimate & 209 & 1 & 0,5 & 0,005 \\
\hline & captan & 209 & 63 & 30,1 & $0,01-0,47$ \\
\hline & carbendazim & 209 & 19 & 9,1 & $0,013-0,26$ \\
\hline & chlorantraniliprole & 209 & 1 & 0,5 & 0,044 \\
\hline & chlorpyrifos & 209 & 9 & 4,3 & $0,005-0,089$ \\
\hline & cyprodinil & 209 & 5 & 2,4 & $0,017-0,075$ \\
\hline & deltamethrin & 209 & 1 & 0,5 & 0,005 \\
\hline & difenoconazole & 209 & 6 & 2,9 & $0,005-0,027$ \\
\hline & diflubenzuron & 209 & 9 & 4,3 & $0,009-0,13$ \\
\hline & dithiocarbamates & 209 & 38 & 18,2 & $0,05-0,61$ \\
\hline & dodine & 209 & 6 & 2,9 & $0,01-0,03$ \\
\hline & fenazaquin $^{\mathrm{N}}$ & 209 & 1 & 0,5 & 0,007 \\
\hline & fenpyroximate & 209 & 5 & 2,4 & $0,006-0,030$ \\
\hline
\end{tabular}


Tabela 3. Pozostałości środków ochrony roślin wykryte w poszczególnych produktach - cd. Table 3. Pesticide residues detected in individual products - continued

\begin{tabular}{|c|c|c|c|c|c|}
\hline 1 & 2 & 3 & 4 & 5 & 6 \\
\hline \multirow{21}{*}{ Jabłka - Apples } & flonicamid & 209 & 11 & 5,3 & $0,005-0,028$ \\
\hline & fludioxonil & 209 & 15 & 7,2 & $0,01-0,22$ \\
\hline & fluopyram & 209 & 24 & 11,5 & $0,005-0,16$ \\
\hline & flutriafol $^{\mathrm{N}}$ & 209 & 1 & 0,5 & 0,008 \\
\hline & hexythiazox & 209 & 2 & 1,0 & $0,007-0,01$ \\
\hline & imidacloprid $^{\mathrm{N}}$ & 209 & 1 & 0,5 & 0,006 \\
\hline & indoxacarb & 209 & 7 & 3,3 & $0,006-0,018$ \\
\hline & methoxyfenozide & 209 & 21 & 10,0 & $0,005-0,28$ \\
\hline & phosmet & 209 & 1 & 0,5 & 0,005 \\
\hline & pirimicarb & 209 & 27 & 12,9 & $0,005-0,05$ \\
\hline & propargite $^{\mathrm{N}}$ & 209 & 1 & 0,5 & 0,02 \\
\hline & propiconazole & 209 & 1 & 0,5 & 0,005 \\
\hline & pyraclostrobin & 209 & 30 & 14,4 & $0,005-0,11$ \\
\hline & pyridaben & 209 & 1 & 0,5 & 0,036 \\
\hline & pyrimethanil & 209 & 9 & 4,3 & $0,005-0,13$ \\
\hline & spirodiclofen & 209 & 4 & 1,9 & $0,01-0,06$ \\
\hline & tebuconazole & 209 & 32 & 15,3 & $0,005-0,15$ \\
\hline & thiacloprid & 209 & 14 & 6,7 & $0,005-0,068$ \\
\hline & thiamethoxam & 209 & 5 & 2,4 & $0,008-0,026$ \\
\hline & thiophanate-methyl & 209 & 8 & 3,8 & $0,01-0,32$ \\
\hline & trifloxystrobin & 209 & 8 & 3,8 & $0,005-0,046$ \\
\hline \multicolumn{6}{|c|}{ Owoce pestkowe - Stone fruits } \\
\hline \multirow{11}{*}{ Brzoskwinie - Peaches } & acetamiprid & 19 & 2 & 10,5 & $0,01-0,02$ \\
\hline & boscalid & 19 & 1 & 5,3 & 0,05 \\
\hline & carbendazim & 19 & 8 & 42,1 & $0,02-0,21$ \\
\hline & chlorpyrifos $^{\mathrm{N}}$ & 19 & 1 & 5,3 & 0,01 \\
\hline & cyprodinil & 19 & 1 & 5,3 & 0,018 \\
\hline & diflubenzuron $^{\mathrm{N}}$ & 19 & 1 & 5,3 & 0,26 \\
\hline & fenpyroximate & 19 & 1 & 5,3 & 0,011 \\
\hline & fludioxonil & 19 & 1 & 5,3 & 0,016 \\
\hline & fluopyram $^{\mathrm{N}}$ & 19 & 1 & 5,3 & 0,026 \\
\hline & pyraclostrobin & 19 & 1 & 5,3 & 0,008 \\
\hline & tebuconazole ${ }^{\mathrm{N}}$ & 19 & 3 & 15,8 & $0,006-0,02$ \\
\hline \multirow{12}{*}{ Czereśnie - Sweet cherries } & acetamiprid & 38 & 13 & 34,2 & $0,009-0,15$ \\
\hline & boscalid & 38 & 4 & 10,5 & $0,033-0,12$ \\
\hline & captan & 38 & 3 & 7,9 & $0,01-0,24$ \\
\hline & carbendazim & 38 & 6 & 15,8 & $0,013-0,097$ \\
\hline & chlorpyrifos $^{\mathrm{N}}$ & 38 & 1 & 2,6 & 0,011 \\
\hline & lambda-cyhalothrin ${ }^{\mathrm{N}}$ & 38 & 1 & 2,6 & 0,007 \\
\hline & cypermethrin $^{\mathrm{N}}$ & 38 & 1 & 2,6 & 0,029 \\
\hline & cyprodinil & 38 & 1 & 2,6 & 0,11 \\
\hline & deltamethrin & 38 & 5 & 13,2 & $0,016-0,056$ \\
\hline & difenoconazole & 38 & 1 & 2,6 & 0,011 \\
\hline & dimethoate & 38 & 1 & 2,6 & 0,026 \\
\hline & fludioxonil & 38 & 1 & 2,6 & 0,036 \\
\hline
\end{tabular}


Tabela 3. Pozostałości środków ochrony roślin wykryte w poszczególnych produktach - cd. Table 3. Pesticide residues detected in individual products - continued

\begin{tabular}{|c|c|c|c|c|c|}
\hline 1 & 2 & 3 & 4 & 5 & 6 \\
\hline \multirow{9}{*}{ Czereśnie - Sweet cherries } & fluopyram $^{\mathrm{N}}$ & 38 & 2 & 5,3 & $0,022-0,07$ \\
\hline & omethoate $^{\mathrm{N}}$ & 38 & 1 & 2,6 & 0,024 \\
\hline & pirimicarb $^{N}$ & 38 & 2 & 5,3 & $0,009-0,024$ \\
\hline & pyraclostrobin & 38 & 1 & 2,6 & 0,026 \\
\hline & pyrimethanil $^{\mathrm{N}}$ & 38 & 1 & 2,6 & 0,006 \\
\hline & tebuconazole $\mathrm{N}^{\mathrm{N}}$ & 38 & 4 & 10,5 & $0,009-0,38$ \\
\hline & thiacloprid & 38 & 7 & 18,4 & $0,008-0,16$ \\
\hline & thiophanate-methyl & 38 & 3 & 7,9 & $0,011-0,053$ \\
\hline & triadimenol $^{\mathrm{N}}$ & 38 & 1 & 2,6 & 0,018 \\
\hline \multirow{9}{*}{ Morele - Apricots } & acetamiprid & 9 & 3 & 33,3 & $0,021-0,042$ \\
\hline & $\operatorname{captan}^{\mathrm{N}}$ & 9 & 1 & 11,1 & 0,03 \\
\hline & carbendazim & 9 & 1 & 11,1 & 0,096 \\
\hline & dimethoate $^{\mathrm{N}}$ & 9 & 2 & 22,2 & $0,088-0,11$ \\
\hline & dithiocarbamates & 9 & 1 & 11,1 & 0,21 \\
\hline & imidacloprid & 9 & 1 & 11,1 & 0,006 \\
\hline & pirimicarb $^{\mathrm{N}}$ & 9 & 1 & 11,1 & 0,06 \\
\hline & thiacloprid & 9 & 1 & 11,1 & 0,016 \\
\hline & thiophanate-methyl & 9 & 2 & 22,2 & $0,019-0,097$ \\
\hline \multirow{22}{*}{ Śliwki - Plums } & acetamiprid & 78 & 13 & 16,7 & $0,005-0,035$ \\
\hline & boscalid & 78 & 6 & 7,7 & $0,006-0,067$ \\
\hline & $\operatorname{captan}^{\mathrm{N}}$ & 78 & 4 & 5,1 & $0,02-0,21$ \\
\hline & carbendazim & 78 & 16 & 20,5 & $0,01-0,054$ \\
\hline & chlorpyrifos & 78 & 2 & 2,6 & 0,007 \\
\hline & cyprodinil & 78 & 5 & 6,4 & $0,04-0,23$ \\
\hline & difenoconazole ${ }^{\mathrm{N}}$ & 78 & 1 & 1,3 & 0,006 \\
\hline & diflubenzuron ${ }^{\mathrm{N}}$ & 78 & 1 & 1,3 & 0,013 \\
\hline & dimethoate $^{\mathrm{N}}$ & 78 & 1 & 1,3 & 0,016 \\
\hline & fenpyroximate & 78 & 3 & 3,8 & $0,006-0,01$ \\
\hline & fenvalerate $^{\mathrm{N}}$ & 78 & 1 & 1,3 & 0,03 \\
\hline & fludioxonil & 78 & 5 & 6,4 & $0,005-0,13$ \\
\hline & fluopyram $^{\mathrm{N}}$ & 78 & 1 & 1,3 & 0,033 \\
\hline & methoxyfenozide & 78 & 1 & 1,3 & 0,005 \\
\hline & pirimicarb $^{\mathrm{N}}$ & 78 & 1 & 1,3 & 0,007 \\
\hline & propiconazole $^{\mathrm{N}}$ & 78 & 1 & 1,3 & 0,016 \\
\hline & pyraclostrobin & 78 & 1 & 1,3 & 0,021 \\
\hline & spirodiclofen & 78 & 3 & 3,8 & $0,017-0,02$ \\
\hline & tebuconazole & 78 & 12 & 15,4 & $0,01-0,15$ \\
\hline & thiacloprid & 78 & 8 & 10,3 & $0,005-0,09$ \\
\hline & thiophanate-methyl & 78 & 5 & 6,4 & $0,012-0,09$ \\
\hline & trifloxystrobin & 78 & 1 & 1,3 & 0,017 \\
\hline \multirow{5}{*}{ Wiśnie - Sour cherries } & acetamiprid & 71 & 19 & 26,8 & $0,005-0,21$ \\
\hline & boscalid & 71 & 5 & 7,0 & $0,017-0,059$ \\
\hline & captan & 71 & 5 & 7,0 & $0,01-0,39$ \\
\hline & carbendazim & 71 & 14 & 19,7 & $0,01-0,14$ \\
\hline & cyprodinil & 71 & 2 & 2,8 & $0,013-0,051$ \\
\hline
\end{tabular}


Tabela 3. Pozostałości środków ochrony roślin wykryte w poszczególnych produktach - cd. Table 3. Pesticide residues detected in individual products - continued

\begin{tabular}{|c|c|c|c|c|c|}
\hline 1 & 2 & 3 & 4 & 5 & 6 \\
\hline \multirow{12}{*}{ Wiśnie - Sour cherries } & deltamethrin & 71 & 2 & 2,8 & $0,026-0,062$ \\
\hline & difenoconazole & 71 & 1 & 1,4 & 0,009 \\
\hline & dimethoate & 71 & 1 & 1,4 & 0,041 \\
\hline & dithiocarbamates & 71 & 5 & 7,0 & $0,05-0,62$ \\
\hline & dodine & 71 & 7 & 9,9 & $0,01-0,44$ \\
\hline & fludioxonil & 71 & 1 & 1,4 & 0,019 \\
\hline & fluopyram & 71 & 2 & 2,8 & $0,026-0,12$ \\
\hline & iprodione & 71 & 1 & 1,4 & 0,63 \\
\hline & omethoate $^{\mathrm{N}}$ & 71 & 1 & 1,4 & 0,037 \\
\hline & tebuconazole & 71 & 4 & 5,6 & $0,006-0,09$ \\
\hline & thiophanate-methyl & 71 & 6 & 8,5 & $0,007-0,029$ \\
\hline & triadimenol & 71 & 8 & 11,3 & $0,006-0,03$ \\
\hline \multicolumn{6}{|c|}{ Owoce jagodowe - Berries } \\
\hline \multirow{24}{*}{ Agrest - Gooseberries } & acetamiprid & 38 & 1 & 2,6 & 0,005 \\
\hline & bupirimate & 38 & 10 & 26,3 & $0,01-0,20$ \\
\hline & captan & 38 & 4 & 10,5 & $0,01-0,09$ \\
\hline & carbendazim & 38 & 1 & 2,6 & 0,14 \\
\hline & chlorpyrifos $^{\mathrm{N}}$ & 38 & 2 & 5,3 & $0,005-0,008$ \\
\hline & cyprodinil $^{\mathrm{N}}$ & 38 & 2 & 5,3 & $0,008-0,012$ \\
\hline & difenoconazole & 38 & 2 & 5,3 & $0,05-0,30$ \\
\hline & dithiocarbamates & 38 & 5 & 13,2 & $0,08-0,63$ \\
\hline & ethirimol & 38 & 1 & 2,6 & 0,017 \\
\hline & fenpyroximate & 38 & 1 & 2,6 & 0,019 \\
\hline & fludioxonil $^{\mathrm{N}}$ & 38 & 2 & 5,3 & $0,005-0,01$ \\
\hline & fluopyram & 38 & 1 & 2,6 & 0,020 \\
\hline & iprodione $^{\mathrm{N}}$ & 38 & 1 & 2,6 & 0,019 \\
\hline & kresoxim-methyl & 38 & 1 & 2,6 & 0,006 \\
\hline & penconazole & 38 & 2 & 5,3 & $0,017-0,03$ \\
\hline & pirimicarb $^{\mathrm{N}}$ & 38 & 1 & 2,6 & 0,26 \\
\hline & pyrimethanil $^{\mathrm{N}}$ & 38 & 1 & 2,6 & 0,006 \\
\hline & propyzamide ${ }^{\mathrm{N}}$ & 38 & 1 & 2,6 & 0,006 \\
\hline & spinosad & 38 & 1 & 2,6 & 0,029 \\
\hline & tebuconazole $\mathrm{N}^{\mathrm{N}}$ & 38 & 2 & 5,3 & $0,006-0,019$ \\
\hline & tetraconaole & 38 & 4 & 10,5 & $0,007-0,083$ \\
\hline & thiacloprid & 38 & 2 & 5,3 & $0,013-0,018$ \\
\hline & trifloxystrobin & 38 & 2 & 5,3 & $0,015-0,13$ \\
\hline & thiophanate-methyl & 38 & 14 & 36,8 & $0,076-0,085$ \\
\hline \multirow{8}{*}{ Maliny - Raspberries } & acetamiprid & 131 & 5 & 3,8 & $0,007-0,05$ \\
\hline & boscalid & 131 & 19 & 14,5 & $0,005-1,67$ \\
\hline & captan & 131 & 3 & 2,3 & $0,02-0,06$ \\
\hline & chlorpyrifos $^{\mathrm{N}}$ & 131 & 2 & 1,5 & $0,018-0,03$ \\
\hline & cyprodinil & 131 & 16 & 12,2 & $0,005-0,95$ \\
\hline & difenoconazole & 131 & 1 & 0,8 & 0,006 \\
\hline & dithiocarbamates & 131 & 2 & 1,5 & $0,05-0,13$ \\
\hline & fenhexamid & 131 & 9 & 6,9 & $0,015-1,64$ \\
\hline
\end{tabular}


Tabela 3. Pozostałości środków ochrony roślin wykryte w poszczególnych produktach - cd.

Table 3. Pesticide residues detected in individual products - continued

\begin{tabular}{|c|c|c|c|c|c|}
\hline 1 & 2 & 3 & 4 & 5 & 6 \\
\hline \multirow{10}{*}{ Maliny - Raspberries } & fenpyroximate & 131 & 2 & 1,5 & 0,024 \\
\hline & fludioxonil & 131 & 15 & 11,5 & $0,008-0,89$ \\
\hline & fluopyram & 131 & 1 & 0,8 & 0,049 \\
\hline & iprodione & 131 & 3 & 2,3 & $0,016-0,73$ \\
\hline & mepanipyrim $^{\mathrm{N}}$ & 131 & 1 & 0,8 & 0,21 \\
\hline & pyrimethanil & 131 & 23 & 17,6 & $0,005-0,64$ \\
\hline & pyraclostrobin & 131 & 15 & 11,5 & $0,007-0,24$ \\
\hline & tebuconazole & 131 & 1 & 0,8 & 0,021 \\
\hline & thiacloprid & 131 & 4 & 3,1 & $0,005-0,069$ \\
\hline & trifloxystrobin & 131 & 4 & 3,1 & $0,01-0,053$ \\
\hline \multirow{27}{*}{ Porzeczki - Currants } & acetamiprid & 123 & 27 & 22,0 & $0,005-0,058$ \\
\hline & boscalid $^{\mathrm{N}}$ & 123 & 2 & 1,6 & $0,017-0,18$ \\
\hline & carbendazim & 123 & 4 & 3,3 & $0,012-0,068$ \\
\hline & chlorpyrifos $^{\mathrm{N}}$ & 123 & 3 & 2,4 & $0,016-0,10$ \\
\hline & cypermethrin $^{\mathrm{N}}$ & 123 & 7 & 5,7 & $0,03-0,22$ \\
\hline & cyprodinil & 123 & 15 & 12,2 & $0,005-0,25$ \\
\hline & deltamethrin & 123 & 7 & 5,7 & $0,007-0,03$ \\
\hline & difenoconazole $\mathrm{N}^{\mathrm{N}}$ & 123 & 9 & 7,3 & $0,01-0,08$ \\
\hline & dithiocarbamates & 123 & 39 & 31,7 & $0,05-1,83$ \\
\hline & fenazaquin $^{\mathrm{N}}$ & 123 & 2 & 1,6 & $0,018-0,11$ \\
\hline & fenhexamid $^{\mathrm{N}}$ & 123 & 1 & 0,8 & 0,15 \\
\hline & fenpyroximate & 123 & 21 & 17,1 & $0,006-0,44$ \\
\hline & fludioxonil & 123 & 3 & 2,4 & $0,014-0,12$ \\
\hline & flutriafol $^{\mathrm{N}}$ & 123 & 1 & 0,8 & 0,03 \\
\hline & kresoxim-methyl & 123 & 1 & 0,8 & 0,01 \\
\hline & picoxystrobin $^{\mathrm{N}}$ & 123 & 1 & 0,8 & 0,017 \\
\hline & pirimicarb $^{\mathrm{N}}$ & 123 & 1 & 0,8 & 0,02 \\
\hline & propiconazole $^{\mathrm{N}}$ & 123 & 1 & 0,8 & 0,11 \\
\hline & pyridaben $^{\mathrm{N}}$ & 123 & 1 & 0,8 & 0,13 \\
\hline & pyraclostrobin & 123 & 2 & 1,6 & $0,009-0,065$ \\
\hline & pyrimethanil ${ }^{\mathrm{N}}$ & 123 & 3 & 2,4 & $0,006-0,092$ \\
\hline & spirodiclofen & 123 & 9 & 7,3 & $0,011-0,10$ \\
\hline & tebuconazole $\mathrm{N}^{\mathrm{N}}$ & 123 & 4 & 3,3 & $0,009-0,03$ \\
\hline & tetraconazole & 123 & 8 & 6,5 & $0,012-0,05$ \\
\hline & thiacloprid & 123 & 23 & 18,7 & $0,005-0,12$ \\
\hline & thiophanate-methyl & 123 & 12 & 9,8 & $0,005-0,11$ \\
\hline & trifloxystrobin & 123 & 30 & 24,4 & $0,005-0,17$ \\
\hline \multirow{8}{*}{ Truskawki - Strawberries } & acetamiprid & 139 & 3 & 2,2 & $0,006-0,03$ \\
\hline & azoxystrobin & 139 & 2 & 1,4 & $0,06-0,09$ \\
\hline & boscalid & 139 & 46 & 33,1 & $0,013-1,35$ \\
\hline & captan & 139 & 2 & 1,4 & $0,01-0,02$ \\
\hline & carbendazim $^{\mathrm{N}}$ & 139 & 2 & 1,4 & $0,01-0,17$ \\
\hline & chlorpyrifos & 139 & 2 & 1,4 & $0,007-0,02$ \\
\hline & cyprodinil & 139 & 17 & 12,2 & $0,01-0,18$ \\
\hline & desmedipham & 139 & 3 & 2,2 & $0,01-0,03$ \\
\hline
\end{tabular}


Tabela 3. Pozostałości środków ochrony roślin wykryte w poszczególnych produktach - cd. Table 3. Pesticide residues detected in individual products - continued

\begin{tabular}{|c|c|c|c|c|c|}
\hline 1 & 2 & 3 & 4 & 5 & 6 \\
\hline \multirow{18}{*}{ Truskawki - Strawberries } & difenoconazole & 139 & 3 & 2,2 & $0,005-0,06$ \\
\hline & dithiocarbamates & 139 & 12 & 8,6 & $0,05-1,24$ \\
\hline & ethirimol ${ }^{\mathrm{N}}$ & 139 & 1 & 0,7 & 0,014 \\
\hline & fenhexamid & 139 & 8 & 5,8 & $0,02-0,95$ \\
\hline & fenpyrazamine & 139 & 2 & 1,4 & $0,028-0,17$ \\
\hline & fenpyroximate & 139 & 2 & 1,4 & $0,01-0,014$ \\
\hline & fluazifop & 139 & 2 & 1,4 & $0,02-0,061$ \\
\hline & fludioxonil & 139 & 18 & 12,9 & $0,006-0,29$ \\
\hline & fluopyram & 139 & 29 & 20,9 & $0,006-0,30$ \\
\hline & folpet $^{\mathrm{N}}$ & 139 & 1 & 0,7 & 0,12 \\
\hline & hexythiazox & 139 & 1 & 0,7 & 0,009 \\
\hline & iprodione & 139 & 1 & 0,7 & 0,15 \\
\hline & mepanipyrim & 139 & 4 & 2,9 & $0,021-0,05$ \\
\hline & pyraclostrobin & 139 & 16 & 11,5 & $0,005-0,08$ \\
\hline & pyrimethanil & 139 & 6 & 4,3 & $0,017-0,18$ \\
\hline & tetraconazole & 139 & 3 & 2,2 & $0,006-0,03$ \\
\hline & thiophanate-methyl & 139 & 1 & 0,7 & 0,005 \\
\hline & trifloxystrobin & 139 & 23 & 16,5 & $0,006-0,18$ \\
\hline \multirow{20}{*}{ Winogrona - Grapes } & azoxystrobin $^{\mathrm{N}}$ & 55 & 4 & 7,3 & $0,052-0,078$ \\
\hline & boscalid $^{\mathrm{N}}$ & 55 & 3 & 5,5 & $0,049-0,14$ \\
\hline & carbendazim & 55 & 11 & 20,0 & $0,016-0,33$ \\
\hline & cyflufenamid & 55 & 4 & 7,3 & $0,03-0,051$ \\
\hline & cymoxanil & 55 & 1 & 1,8 & 0,013 \\
\hline & cyprodinil & 55 & 13 & 23,6 & $0,007-0,43$ \\
\hline & dithiocarbamates & 55 & 9 & 16,4 & $0,05-1,81$ \\
\hline & fenbuconazole & 55 & 1 & 1,8 & 0,42 \\
\hline & fenpyroximate & 55 & 3 & 5,5 & $0,014-0,024$ \\
\hline & fludioxonil & 55 & 13 & 23,6 & $0,011-0,15$ \\
\hline & fluopicolide $^{\mathrm{N}}$ & 55 & 1 & 1,8 & 0,05 \\
\hline & fluopyram & 55 & 1 & 1,8 & 0,48 \\
\hline & iprodione & 55 & 3 & 5,5 & $0,03-0,51$ \\
\hline & iprovalicarb $^{\mathrm{N}}$ & 55 & 1 & 1,8 & 0,011 \\
\hline & metalaxyl & 55 & 11 & 20,0 & $0,01-0,03$ \\
\hline & pyraclostrobin $^{\mathrm{N}}$ & 55 & 3 & 5,5 & $0,013-0,054$ \\
\hline & pyrimethanil & 55 & 1 & 1,8 & 0,014 \\
\hline & propamocarb $^{\mathrm{N}}$ & 55 & 1 & 1,8 & 0,21 \\
\hline & thiophanate-methyl & 55 & 6 & 10,9 & $0,013-0,13$ \\
\hline & trifloxystrobin $^{\mathrm{N}}$ & 55 & 1 & 1,8 & 0,046 \\
\hline \multicolumn{6}{|c|}{ Warzywa - Vegetables } \\
\hline \multicolumn{6}{|c|}{ Warzywa korzeniowe } \\
\hline \multirow{2}{*}{ Chrzan - Horseradishes } & chlorpyrifos $^{\mathrm{N}}$ & 26 & 2 & 7,7 & $0,033-0,25$ \\
\hline & fluazifop & 26 & 1 & 3,8 & 0,011 \\
\hline \multirow{3}{*}{ Marchew - Carrot } & azoxystrobin & 69 & 12 & 17,4 & $0,007-0,086$ \\
\hline & boscalid & 69 & 9 & 13,0 & $0,007-0,093$ \\
\hline & chlorpyrifos $^{\mathrm{N}}$ & 69 & 20 & 29,0 & $0,006-0,103$ \\
\hline
\end{tabular}


Tabela 3. Pozostałości środków ochrony roślin wykryte w poszczególnych produktach - cd.

Table 3. Pesticide residues detected in individual products - continued

\begin{tabular}{|c|c|c|c|c|c|}
\hline 1 & 2 & 3 & 4 & 5 & 6 \\
\hline \multirow{7}{*}{ Marchew - Carrot } & deltamethrin & 69 & 1 & 1,4 & 0,02 \\
\hline & difenoconazole & 69 & 9 & 13,0 & $0,005-0,044$ \\
\hline & linuron & 69 & 14 & 20,3 & $0,005-0,082$ \\
\hline & pendimethalin & 69 & 2 & 2,9 & $0,013-0,017$ \\
\hline & pyraclostrobin & 69 & 3 & 4,3 & $0,005-0,021$ \\
\hline & tebuconazole & 69 & 9 & 13,0 & $0,009-0,13$ \\
\hline & thiacloprid & 69 & 1 & 1,4 & 0,007 \\
\hline \multirow{6}{*}{ Pasternak - Parsnips } & azoxystrobin $^{\mathrm{N}}$ & 15 & 1 & 6,7 & 0,20 \\
\hline & boscalid & 15 & 1 & 6,7 & 0,021 \\
\hline & chlorpyrifos $^{\mathrm{N}}$ & 15 & 1 & 6,7 & 0,008 \\
\hline & epoxiconazole $\mathrm{N}^{\mathrm{N}}$ & 15 & 1 & 6,7 & 0,02 \\
\hline & fluopicolide $^{\mathrm{N}}$ & 15 & 1 & 6,7 & 0,007 \\
\hline & linuron & 15 & 2 & 13,3 & $0,05-0,093$ \\
\hline \multirow{17}{*}{ Pietruszka korzeń - Parsley root } & $\operatorname{azoxystrobin}^{\mathrm{N}}$ & 69 & 2 & 2,9 & $0,01-0,015$ \\
\hline & boscalid & 69 & 7 & 10,1 & $0,024-0,22$ \\
\hline & bupirimate & 69 & 1 & 1,4 & 0,009 \\
\hline & chlorpyrifos $^{\mathrm{N}}$ & 69 & 6 & 8,7 & $0,005-0,05$ \\
\hline & difenoconazole & 69 & 4 & 5,8 & $0,009-0,014$ \\
\hline & dithiocarbamates & 69 & 1 & 1,4 & 0,08 \\
\hline & fluopicolide ${ }^{\mathrm{N}}$ & 69 & 2 & 2,9 & $0,013-0,03$ \\
\hline & fluopyram & 69 & 3 & 4,3 & $0,005-0,02$ \\
\hline & fluorochloridone & 69 & 1 & 1,4 & 0,016 \\
\hline & linuron & 69 & 23 & 33,3 & $0,005-0,15$ \\
\hline & metobromuron $^{\mathrm{N}}$ & 69 & 1 & 1,4 & 0,012 \\
\hline & pendimethalin & 69 & 3 & 4,3 & $0,008-0,01$ \\
\hline & propiconazole $^{\mathrm{N}}$ & 69 & 2 & 2,9 & $0,019-0,02$ \\
\hline & prosulfocarb & 69 & 1 & 1,4 & 0,02 \\
\hline & pyraclostrobin & 69 & 4 & 5,8 & $0,01-0,02$ \\
\hline & tebuconazole & 69 & 5 & 7,2 & $0,008-0,045$ \\
\hline & trifluralin $^{\mathrm{N}}$ & 69 & 1 & 1,4 & 0,064 \\
\hline \multirow{8}{*}{ Rzodkiewka - Radish } & boscalid & 46 & 4 & 8,7 & $0,015-0,17$ \\
\hline & chlorpyrifos $^{\mathrm{N}}$ & 46 & 3 & 6,5 & $0,027-0,16$ \\
\hline & cypermethrin $^{\mathrm{N}}$ & 46 & 1 & 2,2 & 0,04 \\
\hline & dimethoate $^{\mathrm{N}}$ & 46 & 1 & 2,2 & 0,033 \\
\hline & imidacloprid $^{\mathrm{N}}$ & 46 & 1 & 2,2 & 0,033 \\
\hline & iprodione $^{\mathrm{N}}$ & 46 & 1 & 2,2 & 0,089 \\
\hline & propamocarb $^{\mathrm{N}}$ & 46 & 1 & 2,2 & 0,017 \\
\hline & pyraclostrobin & 46 & 1 & 2,2 & 0,065 \\
\hline \multirow{7}{*}{ Seler korzeniowy - Celeriac } & azoxystrobin & 72 & 24 & 33,3 & $0,007-0,52$ \\
\hline & boscalid & 72 & 8 & 11,1 & $0,008-0,16$ \\
\hline & chlorpyrifos $^{\mathrm{N}}$ & 72 & 11 & 15,3 & $0,007-0,733$ \\
\hline & chlorothalonil & 72 & 3 & 4,2 & $0,086-0,13$ \\
\hline & cypermethrin $^{N}$ & 72 & 1 & 1,4 & 0,033 \\
\hline & cyprodinil $^{\mathrm{N}}$ & 72 & 3 & 4,2 & $0,02-0,20$ \\
\hline & difenoconazole & 72 & 14 & 19,4 & $0,009-0,195$ \\
\hline
\end{tabular}


Tabela 3. Pozostałości środków ochrony roślin wykryte w poszczególnych produktach - cd.

Table 3. Pesticide residues detected in individual products - continued

\begin{tabular}{|c|c|c|c|c|c|}
\hline 1 & 2 & 3 & 4 & 5 & 6 \\
\hline \multirow{10}{*}{ Seler korzeniowy - Celeriac } & dithiocarbamates & 72 & 1 & 1,4 & 0,07 \\
\hline & epoxiconazole $\mathrm{N}^{\mathrm{N}}$ & 72 & 1 & 1,4 & 0,26 \\
\hline & fludioxonil $^{\mathrm{N}}$ & 72 & 3 & 4,2 & $0,02-0,22$ \\
\hline & fluopicolide $^{\mathrm{N}}$ & 72 & 1 & 1,4 & 0,02 \\
\hline & fluopyram $^{\mathrm{N}}$ & 72 & 1 & 1,4 & 0,03 \\
\hline & linuron & 72 & 27 & 37,5 & $0,011-0,34$ \\
\hline & pendimethalin & 72 & 3 & 4,2 & $0,016-0,12$ \\
\hline & propamocarb $^{\mathrm{N}}$ & 72 & 2 & 2,8 & $0,028-0,03$ \\
\hline & prosulfocarb & 72 & 2 & 2,8 & $0,012-0,021$ \\
\hline & pyraclostrobin & 72 & 5 & 6,9 & $0,01-0,10$ \\
\hline \multirow{4}{*}{ Ziemniaki - Potatoes } & dithiocarbamates & 40 & 3 & 7,5 & $0,05-0,12$ \\
\hline & imidacloprid & 40 & 4 & 10,0 & $0,015-0,031$ \\
\hline & pencycuron & 40 & 2 & 5,0 & $0,011-0,07$ \\
\hline & propamocarb & 40 & 1 & 2,5 & 0,013 \\
\hline \multicolumn{6}{|c|}{ Warzywa cebulowe - Bulb vegetables } \\
\hline \multirow{2}{*}{ Cebula-Onion } & azoxystrobin & 48 & 1 & 2,1 & 0,012 \\
\hline & boscalid & 48 & 1 & 2,1 & 0,015 \\
\hline \multirow{7}{*}{$\begin{array}{l}\text { Dymka/cebula siedmiolatka } \\
\text { i cebula szczypiorowa } \\
\text { Spring onions/green onions } \\
\text { and welsh onions }\end{array}$} & azoxystrobin & 14 & 3 & 21,4 & $0,019-0,42$ \\
\hline & boscalid & 14 & 2 & 14,3 & $0,029-0,23$ \\
\hline & carbendazim ${ }^{\mathrm{N}}$ & 14 & 1 & 7,1 & 0,017 \\
\hline & chlorpyrifos $^{\mathrm{N}}$ & 14 & 1 & 7,1 & 0,057 \\
\hline & difenoconazole & 14 & 1 & 7,1 & 0,026 \\
\hline & fluopicolide & 14 & 2 & 14,3 & $0,021-0,027$ \\
\hline & propamocarb & 14 & 1 & 7,1 & 0,19 \\
\hline \multicolumn{6}{|c|}{ Warzywa owocowe - Fruiting vegetables } \\
\hline \multirow{17}{*}{ Ogórki - Cucumbers } & azoxystrobin & 54 & 2 & 3,7 & $0,007-0,19$ \\
\hline & carbendazim & 54 & 1 & 1,9 & 0,02 \\
\hline & chlorpyrifos $^{\mathrm{N}}$ & 54 & 1 & 1,9 & 0,007 \\
\hline & chlorothalonil & 54 & 1 & 1,9 & 0,012 \\
\hline & dimethoate ${ }^{\mathrm{N}}$ & 54 & 2 & 3,7 & $0,031-0,059$ \\
\hline & dimethomorph & 54 & 1 & 1,9 & 0,025 \\
\hline & dithiocarbamates & 54 & 2 & 3,7 & $0,14-0,24$ \\
\hline & fenazaquin $^{\mathrm{N}}$ & 54 & 1 & 1,9 & 0,007 \\
\hline & fenpyroximate & 54 & 1 & 1,9 & 0,005 \\
\hline & fluazifop $^{N}$ & 54 & 2 & 3,7 & $0,011-0,021$ \\
\hline & fluopicolide & 54 & 1 & 1,9 & 0,01 \\
\hline & fluopyram $^{\mathrm{N}}$ & 54 & 2 & 3,7 & $0,006-0,02$ \\
\hline & iprodione & 54 & 1 & 1,9 & 0,051 \\
\hline & mandipropamid $^{\mathrm{N}}$ & 54 & 1 & 1,9 & 0,04 \\
\hline & metalaxyl & 54 & 12 & 22,2 & $0,011-0,10$ \\
\hline & propamocarb & 54 & 11 & 20,4 & $0,03-0,34$ \\
\hline & thiophanate-methyl & 54 & 1 & 1,9 & 0,03 \\
\hline \multirow{3}{*}{ Papryka - Sweet pepper } & azoxystrobin & 30 & 2 & 6,7 & $0,013-0,06$ \\
\hline & boscalid & 30 & 1 & 3,3 & 0,19 \\
\hline & chlorpyrifos $^{\mathrm{N}}$ & 30 & 1 & 3,3 & 0,025 \\
\hline
\end{tabular}


Tabela 3. Pozostałości środków ochrony roślin wykryte w poszczególnych produktach - cd.

Table 3. Pesticide residues detected in individual products - continued

\begin{tabular}{|c|c|c|c|c|c|}
\hline 1 & 2 & 3 & 4 & 5 & 6 \\
\hline \multirow{4}{*}{ Papryka - Sweet pepper } & cypermethrin $^{\mathrm{N}}$ & 30 & 1 & 3,3 & 0,05 \\
\hline & propamocarb & 30 & 1 & 3,3 & 0,005 \\
\hline & pyraclostrobin & 30 & 1 & 3,3 & 0,11 \\
\hline & thiophanate-methyl & 30 & 1 & 3,3 & 0,007 \\
\hline \multirow{27}{*}{ Pomidory - Tomatoes } & acetamiprid & 137 & 3 & 2,2 & $0,022-0,13$ \\
\hline & azoxystrobin & 137 & 16 & 11,7 & $0,008-0,35$ \\
\hline & benthiavalicarb isopropyl & 137 & 1 & 0,7 & 0,022 \\
\hline & boscalid & 137 & 18 & 13,1 & $0,01-0,46$ \\
\hline & bupirimate & 137 & 1 & 0,7 & 0,017 \\
\hline & buprofezin ${ }^{\mathrm{N}}$ & 137 & 1 & 0,7 & 0,026 \\
\hline & carbendazim & 137 & 5 & 3,6 & $0,01-0,20$ \\
\hline & chlorantraniliprole $^{\mathrm{N}}$ & 137 & 1 & 0,7 & 0,012 \\
\hline & chlorpyrifos $^{\mathrm{N}}$ & 137 & 1 & 0,7 & 0,014 \\
\hline & chlorothalonil & 137 & 1 & 0,7 & 0,008 \\
\hline & cyprodinil & 137 & 3 & 2,2 & $0,04-0,32$ \\
\hline & difenoconazole & 137 & 1 & 0,7 & 0,025 \\
\hline & dimethomorph & 137 & 3 & 2,2 & $0,01-0,021$ \\
\hline & dithiocarbamates & 137 & 4 & 2,9 & $0,05-0,14$ \\
\hline & famoxadone & 137 & 2 & 1,5 & $0,024-0,03$ \\
\hline & fenamidone & 137 & 2 & 1,5 & $0,006-0,053$ \\
\hline & fludioxonil & 137 & 4 & 2,9 & $0,02-0,11$ \\
\hline & fluopicolide ${ }^{\mathrm{N}}$ & 137 & 7 & 5,1 & $0,008-0,04$ \\
\hline & fluopyram $^{\mathrm{N}}$ & 137 & 4 & 2,9 & $0,01-0,089$ \\
\hline & hyxythiazox & 137 & 2 & 1,5 & $0,015-0,21$ \\
\hline & imidacloprid & 137 & 2 & 1,5 & $0,29-0,47$ \\
\hline & iprodione & 137 & 4 & 2,9 & $0,1-0,89$ \\
\hline & mandipropamid & 137 & 3 & 2,2 & $0,005-0,022$ \\
\hline & propamocarb & 137 & 9 & 6,6 & $0,013-0,12$ \\
\hline & pyraclostrobin & 137 & 12 & 8,8 & $0,005-0,42$ \\
\hline & thiophanate-methyl & 137 & 6 & 4,4 & $0,011-0,15$ \\
\hline & trifloxystrobin ${ }^{\mathrm{N}}$ & 137 & 1 & 0,7 & 0,077 \\
\hline \multicolumn{6}{|c|}{ Warzywa kapustne - Brassica vegetables } \\
\hline \multirow{11}{*}{ Brokuły - Broccoli } & acetamiprid & 61 & 1 & 1,6 & 0,036 \\
\hline & azoxystrobin & 61 & 2 & 3,3 & $0,019-1,06$ \\
\hline & carbendazim & 61 & 1 & 1,6 & 0,026 \\
\hline & chlorpyrifos & 61 & 7 & 11,5 & $0,007-0,027$ \\
\hline & cypermethrin $^{\mathrm{N}}$ & 61 & 2 & 3,3 & $0,021-0,13$ \\
\hline & difenoconazole & 61 & 2 & 3,3 & $0,022-0,46$ \\
\hline & metalaxyl & 61 & 1 & 1,6 & 0,013 \\
\hline & spinosad & 61 & 2 & 3,3 & $0,012-0,046$ \\
\hline & tebuconazole & 61 & 1 & 1,6 & 2,06 \\
\hline & thiacloprid & 61 & 2 & 3,3 & $0,011-0,34$ \\
\hline & thiophanate-methyl ${ }^{\mathrm{N}}$ & 61 & 1 & 1,6 & 0,037 \\
\hline \multirow{2}{*}{ Jarmuż - Kales } & chlorpyrifos $^{\mathrm{N}}$ & 8 & 2 & 25,0 & $0,007-0,018$ \\
\hline & fluopyram $^{\mathrm{N}}$ & 8 & 1 & 12,5 & 0,015 \\
\hline
\end{tabular}


Tabela 3. Pozostałości środków ochrony roślin wykryte w poszczególnych produktach - cd.

Table 3. Pesticide residues detected in individual products - continued

\begin{tabular}{|c|c|c|c|c|c|}
\hline 1 & 2 & 3 & 4 & 5 & 6 \\
\hline \multirow{5}{*}{ Jarmuż - Kales } & linuron $^{\mathrm{N}}$ & 8 & 1 & 12,5 & 0,014 \\
\hline & metalaxyl ${ }^{\mathrm{N}}$ & 8 & 2 & 25,0 & $0,012-0,016$ \\
\hline & metribuzin $^{\mathrm{N}}$ & 8 & 1 & 12,5 & 0,044 \\
\hline & terbuthylazine $\mathrm{N}^{\mathrm{N}}$ & 8 & 1 & 12,5 & 0,011 \\
\hline & thiacloprid $^{\mathrm{N}}$ & 8 & 1 & 12,5 & 0,084 \\
\hline \multirow{2}{*}{ Kalafior - Cauliflower } & boscalid & 38 & 1 & 2,6 & 0,007 \\
\hline & propamocarb & 38 & 1 & 2,6 & 0,011 \\
\hline \multirow{4}{*}{$\begin{array}{l}\text { Kapusta głowiasta }- \text { Head } \\
\text { cabbage }\end{array}$} & acetamiprid & 69 & 1 & 1,4 & 0,048 \\
\hline & chlorpyrifos & 69 & 1 & 1,4 & 0,007 \\
\hline & difenoconazole & 69 & 1 & 1,4 & 0,068 \\
\hline & propamocarb & 69 & 1 & 1,4 & 0,019 \\
\hline \multirow{4}{*}{$\begin{array}{l}\text { Kapusta brukselska - Brussels } \\
\text { sprouts }\end{array}$} & boscalid & 19 & 1 & 5,3 & 0,037 \\
\hline & chlorpyrifos & 19 & 4 & 21,1 & $0,01-0,035$ \\
\hline & tebuconazole & 19 & 2 & 10,5 & $0,01-0,03$ \\
\hline & thiacloprid & 19 & 1 & 5,3 & 0,011 \\
\hline \multirow{22}{*}{$\begin{array}{l}\text { Kapusta pekińska - Chinese } \\
\text { cabbage }\end{array}$} & acetamiprid & 93 & 5 & 5,4 & $0,005-0,026$ \\
\hline & azoxystrobin & 93 & 11 & 11,8 & $0,006-0,04$ \\
\hline & bifenthrin $^{\mathrm{N}}$ & 93 & 1 & 1,1 & 0,011 \\
\hline & boscalid $^{\mathrm{N}}$ & 93 & 2 & 2,2 & $0,20-0,83$ \\
\hline & carbendazim $^{\mathrm{N}}$ & 93 & 3 & 3,2 & $0,02-0,041$ \\
\hline & chlorothalonil $^{\mathrm{N}}$ & 93 & 2 & 2,2 & $0,011-0,026$ \\
\hline & chlorpyrifos ${ }^{\mathrm{N}}$ & 93 & 14 & 15,1 & $0,01-0,21$ \\
\hline & cypermethrin $^{\mathrm{N}}$ & 93 & 2 & 2,2 & $0,011-0,021$ \\
\hline & deltamethrin & 93 & 2 & 2,2 & $0,012-0,016$ \\
\hline & difenoconazole & 93 & 2 & 2,2 & $0,011-0,051$ \\
\hline & dimethoate $^{\mathrm{N}}$ & 93 & 8 & 8,6 & $0,006-0,11$ \\
\hline & flonicamid $^{\mathrm{N}}$ & 93 & 1 & 1,1 & 0,04 \\
\hline & fluopyram & 93 & 1 & 1,1 & 0,009 \\
\hline & imidacloprid $^{\mathrm{N}}$ & 93 & 4 & 4,3 & $0,011-0,025$ \\
\hline & iprodione & 93 & 4 & 4,3 & $0,024-1,49$ \\
\hline & linuron $^{\mathrm{N}}$ & 93 & 1 & 1,1 & 0,01 \\
\hline & propamocarb $^{\mathrm{N}}$ & 93 & 1 & 1,1 & 0,019 \\
\hline & pyrimethanil $^{\mathrm{N}}$ & 93 & 2 & 2,2 & $0,007-0,009$ \\
\hline & pyraclostrobin ${ }^{\mathrm{N}}$ & 93 & 2 & 2,2 & $0,229-0,28$ \\
\hline & tebuconazole & 93 & 2 & 2,2 & $0,005-0,04$ \\
\hline & thiacloprid & 93 & 6 & 6,5 & $0,005-0,02$ \\
\hline & thiophanate-methyl $^{\mathrm{N}}$ & 93 & 3 & 3,2 & $0,005-0,17$ \\
\hline \multirow{3}{*}{ Rukola - Rucola } & boscalid & 13 & 2 & 15,4 & $0,016-3,82$ \\
\hline & chlorpyrifos $^{\mathrm{N}}$ & 13 & 2 & 15,4 & $0,01-0,015$ \\
\hline & pyraclostrobin & 13 & 1 & 7,7 & 0,61 \\
\hline \multicolumn{6}{|c|}{ Warzywa liściowe i świeże zioła - Leaf vegetables and fresh herbs } \\
\hline \multirow{4}{*}{ Koper - Dill } & azoxystrobin $^{\mathrm{N}}$ & 63 & 1 & 1,6 & 0,068 \\
\hline & boscalid & 63 & 1 & 1,6 & 0,26 \\
\hline & carbendazim $^{\mathrm{N}}$ & 63 & 2 & 3,2 & $0,017-0,03$ \\
\hline & clothianidin & 63 & 1 & 1,6 & 0,04 \\
\hline
\end{tabular}


Tabela 3. Pozostałości środków ochrony roślin wykryte w poszczególnych produktach - cd. Table 3. Pesticide residues detected in individual products - continued

\begin{tabular}{|c|c|c|c|c|c|}
\hline 1 & 2 & 3 & 4 & 5 & 6 \\
\hline \multirow{18}{*}{ Koper - Dill } & chlorpyrifos $^{\mathrm{N}}$ & 63 & 27 & 42,9 & $0,007-0,44$ \\
\hline & cyprodinil $^{\mathrm{N}}$ & 63 & 1 & 1,6 & 0,02 \\
\hline & difenoconazole & 63 & 1 & 1,6 & 0,013 \\
\hline & dimethoate $^{\mathrm{N}}$ & 63 & 1 & 1,6 & 0,01 \\
\hline & fenpropidin $^{\mathrm{N}}$ & 63 & 1 & 1,6 & 0,012 \\
\hline & fluopicolide ${ }^{\mathrm{N}}$ & 63 & 1 & 1,6 & 0,33 \\
\hline & linuron & 63 & 12 & 19,0 & $0,012-0,32$ \\
\hline & metalaxyl ${ }^{\mathrm{N}}$ & 63 & 1 & 1,6 & 0,051 \\
\hline & metribuzin $^{N}$ & 63 & 1 & 1,6 & 0,025 \\
\hline & pendimethalin & 63 & 11 & 17,5 & $0,007-0,14$ \\
\hline & prometryn $^{\mathrm{N}}$ & 63 & 1 & 1,6 & 0,04 \\
\hline & propamocarb $^{\mathrm{N}}$ & 63 & 1 & 1,6 & 3,01 \\
\hline & propiconazole ${ }^{\mathrm{N}}$ & 63 & 1 & 1,6 & 4,89 \\
\hline & prosulfocarb $^{N}$ & 63 & 2 & 3,2 & $0,014-0,028$ \\
\hline & pyraclostrobin & 63 & 1 & 1,6 & 0,086 \\
\hline & tebuconazole $\mathrm{N}^{\mathrm{N}}$ & 63 & 2 & 3,2 & $0,009-0,03$ \\
\hline & tetraconazole $\mathrm{N}^{\mathrm{N}}$ & 63 & 1 & 1,6 & 0,049 \\
\hline & thiophanate-methyl ${ }^{\mathrm{N}}$ & 63 & 1 & 1,6 & 0,011 \\
\hline \multirow{23}{*}{ Sałata - Lettuce } & azoxystrobin & 76 & 12 & 15,8 & $0,009-4,87$ \\
\hline & boscalid & 76 & 4 & 5,3 & $0,037-5,08$ \\
\hline & carbendazim $^{\mathrm{N}}$ & 76 & 1 & 1,3 & 0,075 \\
\hline & chlorothalonil $^{\mathrm{N}}$ & 76 & 1 & 1,3 & 0,5 \\
\hline & chlorpyrifos $^{\mathrm{N}}$ & 76 & 3 & 3,9 & $0,012-0,05$ \\
\hline & lambda-cyhalothrin $^{N}$ & 76 & 1 & 1,3 & 0,027 \\
\hline & cyprodinil & 76 & 1 & 1,3 & 0,015 \\
\hline & cyproconazole $\mathrm{N}^{\mathrm{N}}$ & 76 & 1 & 1,3 & 0,013 \\
\hline & difenoconazole & 76 & 2 & 2,6 & $0,005-0,008$ \\
\hline & dithiocarbamates & 76 & 3 & 3,9 & $0,05-1,42$ \\
\hline & famoxadon $^{\mathrm{N}}$ & 76 & 1 & 1,3 & 0,067 \\
\hline & fluopicolide ${ }^{\mathrm{N}}$ & 76 & 1 & 1,3 & 0,046 \\
\hline & imidacloprid $^{\mathrm{N}}$ & 76 & 2 & 2,6 & $0,029-0,075$ \\
\hline & linuron $^{\mathrm{N}}$ & 76 & 1 & 1,3 & 0,051 \\
\hline & metalaxyl & 76 & 2 & 2,6 & $0,017-0,019$ \\
\hline & metribuzin $^{\mathrm{N}}$ & 76 & 3 & 3,9 & $0,013-0,033$ \\
\hline & pendimethalin & 76 & 3 & 3,9 & $0,01-0,05$ \\
\hline & picoxystrobin $^{\mathrm{N}}$ & 76 & 1 & 1,3 & 0,019 \\
\hline & propamocarb & 76 & 2 & 2,6 & $0,011-0,26$ \\
\hline & pyraclostrobin & 76 & 3 & 3,9 & $0,006-1,0$ \\
\hline & spirotetramat & 76 & 1 & 1,3 & 0,026 \\
\hline & tetraconazole $\mathrm{N}^{\mathrm{N}}$ & 76 & 1 & 1,3 & 0,023 \\
\hline & thiophanate-methyl ${ }^{\mathrm{N}}$ & 76 & 2 & 2,6 & $0,084-0,26$ \\
\hline \multirow{4}{*}{ Szczypiorek-Chives } & boscalid & 18 & 3 & 16,7 & $0,033-0,21$ \\
\hline & chlorpyrifos $^{\mathrm{N}}$ & 18 & 1 & 5,6 & 0,028 \\
\hline & fluopicolide $^{\mathrm{N}}$ & 18 & 1 & 5,6 & 0,01 \\
\hline & linuron $^{\mathrm{N}}$ & 18 & 1 & 5,6 & 0,017 \\
\hline
\end{tabular}


Tabela 3. Pozostałości środków ochrony roślin wykryte w poszczególnych produktach - cd.

Table 3. Pesticide residues detected in individual products - continued

\begin{tabular}{|c|c|c|c|c|c|}
\hline 1 & 2 & 3 & 4 & 5 & 6 \\
\hline Szczypiorek - Chives & thiacloprid $^{\mathrm{N}}$ & 18 & 1 & 5,6 & 0,21 \\
\hline \multirow{5}{*}{ Szpinak - Spinaches } & chlorpyrifos $^{\mathrm{N}}$ & 42 & 2 & 4,8 & $0,02-0,04$ \\
\hline & desmedipham $^{\mathrm{N}}$ & 42 & 1 & 2,4 & 0,03 \\
\hline & dimethoate $^{\mathrm{N}}$ & 42 & 1 & 2,4 & 0,009 \\
\hline & etofenprox ${ }^{\mathrm{N}}$ & 42 & 1 & 2,4 & 0,051 \\
\hline & propamocarb $^{\mathrm{N}}$ & 42 & 1 & 2,4 & 0,005 \\
\hline \multicolumn{6}{|c|}{ Warzywa strączkowe - Legume vegetables } \\
\hline \multirow{2}{*}{ Bób - Broad bean } & acetamiprid & 20 & 2 & 10,0 & $0,015-0,06$ \\
\hline & thiacloprid $^{\mathrm{N}}$ & 20 & 1 & 5,0 & 0,021 \\
\hline \multirow{2}{*}{ Fasola szparagowa - String bean } & azoxystrobin & 11 & 1 & 9,1 & 0,01 \\
\hline & dithiocarbamates & 11 & 2 & 18,2 & $0,05-0,07$ \\
\hline \multirow{3}{*}{ Groszek zielony - Green pea } & acetamiprid & 15 & 1 & 6,7 & 0,022 \\
\hline & azoxystrobin & 15 & 4 & 26,7 & $0,008-0,013$ \\
\hline & thiacloprid & 15 & 2 & 13,3 & $0,013-0,021$ \\
\hline \multicolumn{6}{|c|}{ Warzywa łodygowe - Stem vegetables } \\
\hline \multirow{6}{*}{ Por - Leek } & azoxystrobin & 80 & 5 & 6,3 & $0,005-0,28$ \\
\hline & chlorpyrifos $^{\mathrm{N}}$ & 80 & 2 & 2,5 & $0,21-0,64$ \\
\hline & difenoconazole & 80 & 1 & 1,3 & 0,006 \\
\hline & linuron & 80 & 1 & 1,3 & 0,011 \\
\hline & spinosad & 80 & 1 & 1,3 & 0,02 \\
\hline & spiroxamine $^{\mathrm{N}}$ & 80 & 1 & 1,3 & 0,01 \\
\hline Szparagi - Asparagus & dithiocarbamates $^{\mathrm{N}}$ & 5 & 1 & 20,0 & 0,05 \\
\hline \multicolumn{6}{|c|}{ Grzyby - Fungi } \\
\hline \multirow{4}{*}{ Pieczarki - Mushrooms } & carbendazim & 70 & 3 & 4,3 & $0,01-0,19$ \\
\hline & diflubenzuron ${ }^{\mathrm{N}}$ & 70 & 5 & 7,1 & $0,012-0,07$ \\
\hline & prochloraz & 70 & 22 & 31,4 & $0,006-0,08$ \\
\hline & thiophanate-methyl & 70 & 1 & 1,4 & 0,094 \\
\hline \multicolumn{6}{|c|}{ Jadalne nasiona roślin strączkowych - Pulses } \\
\hline \multirow{2}{*}{ Fasola - Bean } & pyrimiphos-methyl & 32 & 1 & 3,1 & 0,014 \\
\hline & methiocarb $^{\mathrm{N}}$ & 32 & 1 & 3,1 & 0,054 \\
\hline \multirow{2}{*}{ Groch - Pea } & chlorpyrifos $^{\mathrm{N}}$ & 26 & 1 & 3,8 & 0,018 \\
\hline & pyrimiphos-methyl & 26 & 1 & 3,8 & 0,013 \\
\hline \multicolumn{6}{|c|}{ Nasiona oleiste - Oilseeds } \\
\hline \multirow{12}{*}{ Rzepak - Rapeseed } & boscalid & 130 & 3 & 2,3 & $0,006-0,018$ \\
\hline & clomazone & 130 & 1 & 0,8 & 0,011 \\
\hline & chlorpyrifos & 130 & 4 & 3,1 & $0,014-0,092$ \\
\hline & cypermethrin & 130 & 1 & 0,8 & 0,03 \\
\hline & difenoconazole & 130 & 3 & 2,3 & $0,013-0,022$ \\
\hline & fluopyram & 130 & 3 & 2,3 & $0,012-0,036$ \\
\hline & glyphosate & 130 & 23 & 17,7 & $0,05-0,15$ \\
\hline & mepiquat & 130 & 1 & 0,8 & 0,01 \\
\hline & methiocarb $^{\mathrm{N}}$ & 130 & 1 & 0,8 & 0,045 \\
\hline & pyrimiphos-methyl & 130 & 9 & 6,9 & $0,011-12,23$ \\
\hline & tebuconazole & 130 & 7 & 5,4 & $0,008-0,042$ \\
\hline & tetraconazole & 130 & 8 & 6,2 & $0,007-0,034$ \\
\hline
\end{tabular}


Tabela 3. Pozostałości środków ochrony roślin wykryte w poszczególnych produktach - cd.

Table 3. Pesticide residues detected in individual products - continued

\begin{tabular}{|c|c|c|c|c|c|}
\hline 1 & 2 & 3 & 4 & 5 & 6 \\
\hline Rzepak - Rapeseed & thiacloprid & 130 & 3 & 2,3 & $0,006-0,029$ \\
\hline Soja - Soya bean & pyrimiphos-methyl & 10 & 1 & 10,0 & 0,017 \\
\hline \multicolumn{6}{|c|}{ Zboża - Cereals } \\
\hline \multirow{4}{*}{ Gryka - Buckwheat } & flufenacet $^{\mathrm{N}}$ & 21 & 1 & 4,8 & 0,056 \\
\hline & carbendazim $^{\mathrm{N}}$ & 21 & 1 & 4,8 & 0,019 \\
\hline & metribuzin $^{\mathrm{N}}$ & 21 & 1 & 4,8 & 0,023 \\
\hline & pirimiphos-methyl & 21 & 1 & 4,8 & 0,0098 \\
\hline \multirow{7}{*}{ Jęczmień - Barley } & azoxystrobin & 27 & 1 & 3,7 & 0,014 \\
\hline & cypermethrin & 27 & 1 & 3,7 & 0,097 \\
\hline & cyproconazole & 27 & 2 & 7,4 & $0,063-0,066$ \\
\hline & cyprodinil & 27 & 1 & 3,7 & 0,01 \\
\hline & epoxiconazole & 27 & 3 & 11,1 & $0,011-0,016$ \\
\hline & pirimiphos-methyl & 27 & 6 & 22,2 & $0,0072-0,25$ \\
\hline & tebuconazole & 27 & 3 & 11,1 & $0,011-0,069$ \\
\hline Kukurydza - Corn & pirimiphos-methyl & 48 & 1 & 2,1 & 0,045 \\
\hline Mieszanka zbożowa - Cereal mix & pirimiphos-methyl & 48 & 6 & 12,5 & $0,005-0,29$ \\
\hline Owies - Oat & pirimiphos-methyl & 27 & 4 & 14,8 & $0,005-0,035$ \\
\hline \multirow{2}{*}{ Proso - Common millet } & carboxin $^{\mathrm{N}}$ & 9 & 1 & 11,1 & 0,02 \\
\hline & pirimiphos-methyl & 9 & 1 & 11,1 & 0,011 \\
\hline \multirow{7}{*}{ Pszenica - Wheat } & chlorpyrifos & 66 & 2 & 3,0 & $0,018-0,036$ \\
\hline & deltamethrin & 66 & 1 & 1,5 & 0,11 \\
\hline & fenpropidin & 66 & 1 & 1,5 & 0,023 \\
\hline & fenpropimorph & 66 & 1 & 1,5 & 0,007 \\
\hline & imidacloprid & 66 & 1 & 1,5 & 0,015 \\
\hline & pirimiphos-methyl & 66 & 6 & 9,1 & $0,012-0,071$ \\
\hline & tebuconazole & 66 & 4 & 6,1 & $0,006-0,024$ \\
\hline \multirow{3}{*}{ Pszenżyto - Triticale } & pencycuron $^{\mathrm{N}}$ & 89 & 1 & 1,1 & 0,013 \\
\hline & pirimiphos-methyl & 89 & 11 & 12,4 & $0,0064-0,14$ \\
\hline & tebuconazole & 89 & 1 & 1,1 & 0,02 \\
\hline \multirow{2}{*}{ Żyto - Rye } & pirimiphos-methyl & 62 & 4 & 6,5 & $0,011-0,34$ \\
\hline & tebuconazole & 62 & 1 & 1,6 & 0,021 \\
\hline \multicolumn{6}{|c|}{ Rośliny cukrodajne - Sugar plants } \\
\hline \multirow{6}{*}{ Burak cukrowy - Sugarbeet root } & desmedipham & 62 & 1 & 1,6 & 0,01 \\
\hline & difenoconazole & 62 & 2 & 3,2 & $0,02-0,027$ \\
\hline & epoxiconazole & 62 & 9 & 14,5 & $0,005-0,015$ \\
\hline & fenpropimorph & 62 & 1 & 1,6 & 0,011 \\
\hline & pyraclostrobin & 62 & 1 & 1,6 & 0,007 \\
\hline & tetraconazole & 62 & 4 & 6,5 & $0,005-0,01$ \\
\hline \multicolumn{6}{|c|}{ Przyprawy - Spices } \\
\hline \multirow{5}{*}{ Kminek - Black caraway } & boscalid $^{\mathrm{N}}$ & 9 & 1 & 11,1 & 0,028 \\
\hline & chlorpyrifos $^{\mathrm{N}}$ & 9 & 5 & 55,6 & $0,011-0,043$ \\
\hline & cyprodinil $^{\mathrm{N}}$ & 9 & 2 & 22,2 & $0,026-0,26$ \\
\hline & ethofumesate & 9 & 1 & 11,1 & 0,016 \\
\hline & fludioxonil $^{\mathrm{N}}$ & 9 & 2 & 22,2 & $0,013-0,21$ \\
\hline
\end{tabular}

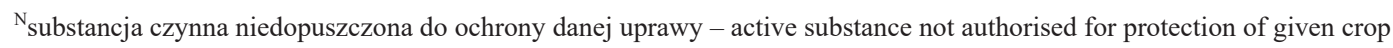


Tabela 4. Produkty, w których stwierdzono przekroczenia najwyższych dopuszczalnych poziomów pozostałości

Table 4. Products with residues exceeding maximum residue levels

\begin{tabular}{|c|c|c|c|c|c|c|}
\hline \multirow{2}{*}{$\begin{array}{l}\text { Produkt } \\
\text { Product }\end{array}$} & \multirow{2}{*}{$\begin{array}{l}\text { Związek } \\
\text { Compound }\end{array}$} & \multirow{2}{*}{$\begin{array}{l}\text { Liczba } \\
\text { badanych } \\
\text { próbek } \\
\text { Number of } \\
\text { analysed } \\
\text { samples }\end{array}$} & \multicolumn{2}{|c|}{$\begin{array}{l}\text { Przekroczenia NDP } \\
\text { MRLs exceedances }\end{array}$} & \multirow{2}{*}{$\begin{array}{l}\text { Poziom pozostałości } \\
\text { Residue level } \\
{[\mathrm{mg} / \mathrm{kg}]}\end{array}$} & \multirow{2}{*}{$\begin{array}{c}\mathrm{NDP}^{1} \\
\mathrm{MRL} \\
{[\mathrm{mg} / \mathrm{kg}]}\end{array}$} \\
\hline & & & $\begin{array}{l}\text { liczba } \\
\text { number }\end{array}$ & $\begin{array}{l}\text { procent } \\
\text { percent }\end{array}$ & & \\
\hline Agrest - Gooseberries & difenoconazole & 38 & 1 & 2,6 & 0,3 & 0,1 \\
\hline Brokuły - Broccoli & tebuconazole & 61 & 1 & 1,6 & 2,06 & 0,15 \\
\hline Chrzan - Horseradishes & chlorpyrifos $^{\mathrm{N}}$ & 26 & 1 & 3,8 & 0,25 & 0,05 \\
\hline Gruszki - Pears & chlorpyrifos $^{\mathrm{N}}$ & 70 & 1 & 1,4 & 0,024 & 0,01 \\
\hline Jabłka - Apples & chlorpyrifos & 209 & 3 & 1,4 & $0,042-0,089$ & 0,01 \\
\hline Kapusta pekińska - Chinese cabbage & chlorpyrifos $^{\mathrm{N}}$ & 93 & 9 & 9,7 & $0,03-0,21$ & 0,01 \\
\hline \multirow{2}{*}{ Kapusta pekińska - Chinese cabbage } & chlorpyrifos $^{\mathrm{N}}$ & \multirow{2}{*}{93} & \multirow{2}{*}{1} & \multirow{2}{*}{1,1} & 0,121 & 0,01 \\
\hline & chlorothalonil $^{\mathrm{N}}$ & & & & 0,026 & 0,01 \\
\hline Kapusta pekińska - Chinese cabbage & dimethoate $^{\mathrm{N}}$ & 93 & 2 & 2,2 & $0,087-0,11$ & 0,02 \\
\hline Kapusta pekińska - Chinese cabbage & iprodione & 93 & 1 & 1,1 & 1,49 & 0,7 \\
\hline \multirow{2}{*}{ Kminek - Black caraway } & cyprodinil $^{\mathrm{N}}$ & \multirow{2}{*}{9} & \multirow{2}{*}{1} & \multirow{2}{*}{11,1} & 0,26 & 0,1 \\
\hline & fludioxonil $^{\mathrm{N}}$ & & & & 0,21 & 0,05 \\
\hline Koper-Dill & chlorpyrifos $^{\mathrm{N}}$ & 63 & 6 & 9,5 & $0,124-0,57$ & 0,05 \\
\hline Koper-Dill & propiconazole $^{\mathrm{N}}$ & 63 & 1 & 1,6 & 4,89 & 0,05 \\
\hline \multirow{2}{*}{ Koper - Dill } & chlorpyrifos $^{\mathrm{N}}$ & \multirow{2}{*}{63} & \multirow{2}{*}{1} & \multirow{2}{*}{1,6} & 0,13 & 0,05 \\
\hline & tetraconazole ${ }^{\mathrm{N}}$ & & & & 0,049 & 0,02 \\
\hline Koper - Dill & clothianidin $^{\mathrm{N}}$ & 63 & 1 & 1,6 & 0,04 & 0,01 \\
\hline Koper-Dill & prometryn $^{\mathrm{N}}$ & 63 & 1 & 1,6 & 0,04 & 0,01 \\
\hline Maliny - Raspberries & chlorpyrifos $^{\mathrm{N}}$ & 131 & 1 & 0,8 & 0,03 & 0,01 \\
\hline Maliny - Raspberries & dithiocarbamates & 131 & 1 & 0,8 & 0,13 & 0,05 \\
\hline Morele - Apricots & dimethoate $^{\mathrm{N}}$ & 9 & 2 & 22,2 & $0,088-0,113$ & 0,02 \\
\hline Ogórki - Cucumbers & dimethoate $^{\mathrm{N}}$ & 54 & 1 & 1,9 & 0,059 & 0,02 \\
\hline Papryka - Sweet pepper & chlorpyrifos $^{\mathrm{N}}$ & 30 & 1 & 3,3 & 0,025 & 0,01 \\
\hline Pietruszka (korzeń) - Parsley (root) & trifluralin $^{\mathrm{N}}$ & 69 & 1 & 1,4 & 0,064 & 0,01 \\
\hline Por - Leek & chlorpyrifos $^{\mathrm{N}}$ & 80 & 2 & 2,5 & $0,21-0,64$ & 0,01 \\
\hline Porzeczki - Currants & chlorpyrifos $^{\mathrm{N}}$ & 123 & 2 & 1,6 & $0,072-0,1$ & 0,01 \\
\hline Porzeczki - Currants & cypermethrin $^{\mathrm{N}}$ & 123 & 1 & 0,8 & 0,22 & 0,05 \\
\hline Porzeczki - Currants & fenazaquin $^{\mathrm{N}}$ & 123 & 1 & 0,8 & 0,11 & 0,01 \\
\hline Porzeczki - Currants & flutriafol $^{\mathrm{N}}$ & 123 & 1 & 0,8 & 0,03 & 0,01 \\
\hline Porzeczki - Currants & propiconazole $^{\mathrm{N}}$ & 123 & 1 & 0,8 & 0,11 & 0,01 \\
\hline Rzepak - Rapeseed & pyrimiphos-methyl & 130 & 1 & 0,8 & 12,227 & 0,5 \\
\hline \multirow{2}{*}{ Sałata - Lettuce } & chlorothalonil $^{\mathrm{N}}$ & \multirow{2}{*}{76} & \multirow{2}{*}{1} & \multirow{2}{*}{1,3} & 0,50 & 0,01 \\
\hline & thiophanate-methyl ${ }^{\mathrm{N}}$ & & & & 0,265 & 0,1 \\
\hline Sałata - Lettuce & famoxadon $^{\mathrm{N}}$ & 76 & 1 & 1,3 & 0,067 & 0,01 \\
\hline Seler korzeniowy - Celeriac & chlorpyrifos $^{\mathrm{N}}$ & 72 & 3 & 4,2 & $0,19-0,733$ & 0,05 \\
\hline Seler korzeniowy - Celeriac & epoxiconazole ${ }^{\mathrm{N}}$ & 72 & 1 & 1,4 & 0,26 & 0,05 \\
\hline Szpinak - Spinaches & desmedipham $^{\mathrm{N}}$ & 42 & 1 & 2,4 & 0,03 & 0,01 \\
\hline Truskawki - Strawberries & desmedipham & 139 & 1 & 0,7 & 0,03 & 0,01 \\
\hline Winogrona - Grapes & propamocarb $^{\mathrm{N}}$ & 55 & 1 & 1,8 & 0,21 & 0,01 \\
\hline Ogólem - Overall & & 3019 & 56 & 1,9 & - & - \\
\hline
\end{tabular}

${ }^{1}$ najwyższe dopuszczalne poziomy pozostałości - Maximum Residue Levels

${ }^{\mathrm{N}}$ niedopuszczona substancja czynna - unauthorised active substance 


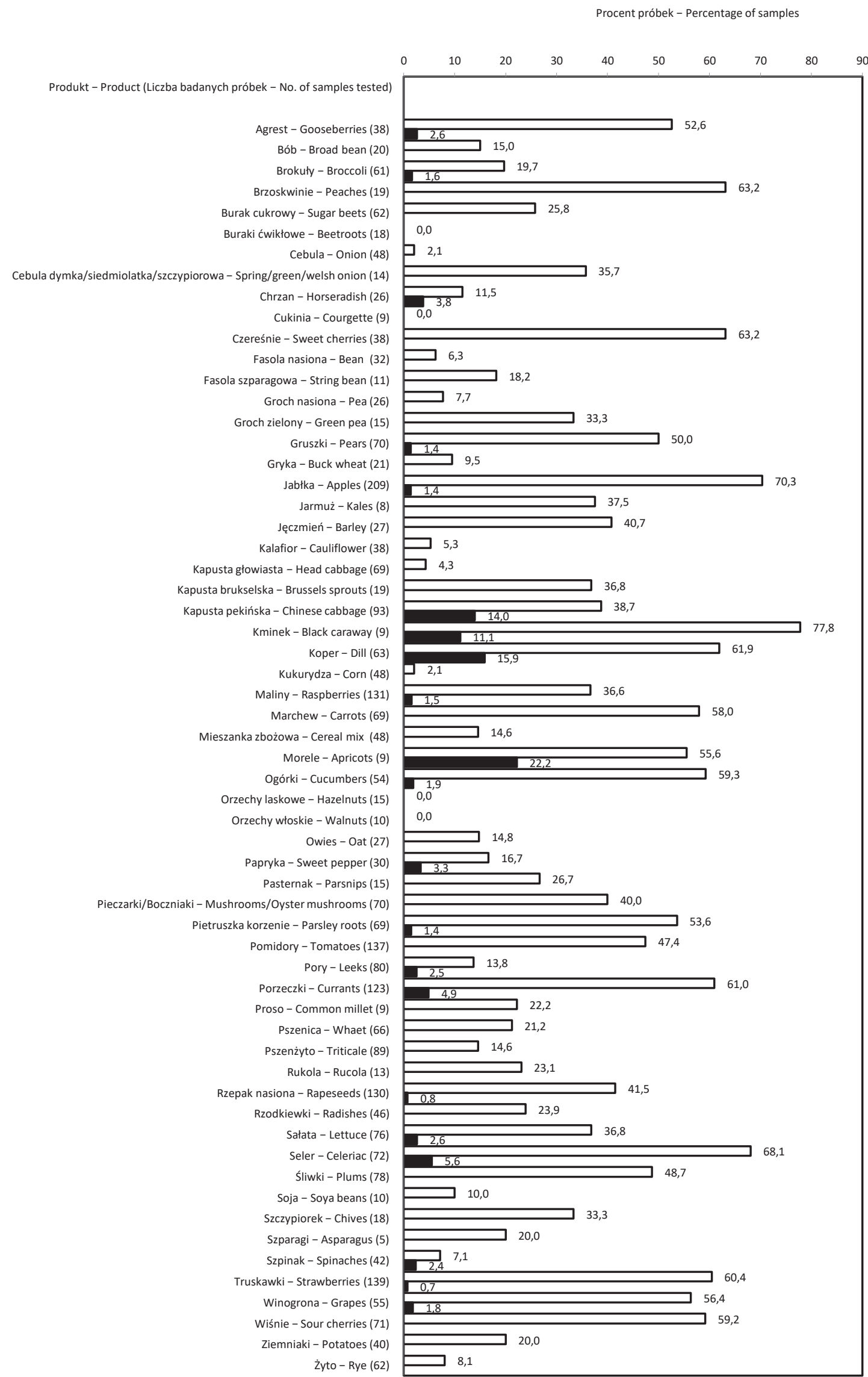

QPróbki z pozostałościami - Samples with residues

—Próbki z pozostałościami > NDP - Samples with residues > MRLs

Rys. 3. Częstotliwość występowania pozostałości środków ochrony roślin i przekroczeń NDP w poszczególnych produktach (2016-2017) Fig. 3. Frequency of occurrence of pesticide residues and MRL exceedances in individual products (2016-2017) 
Procent próbek - Percentage of samples

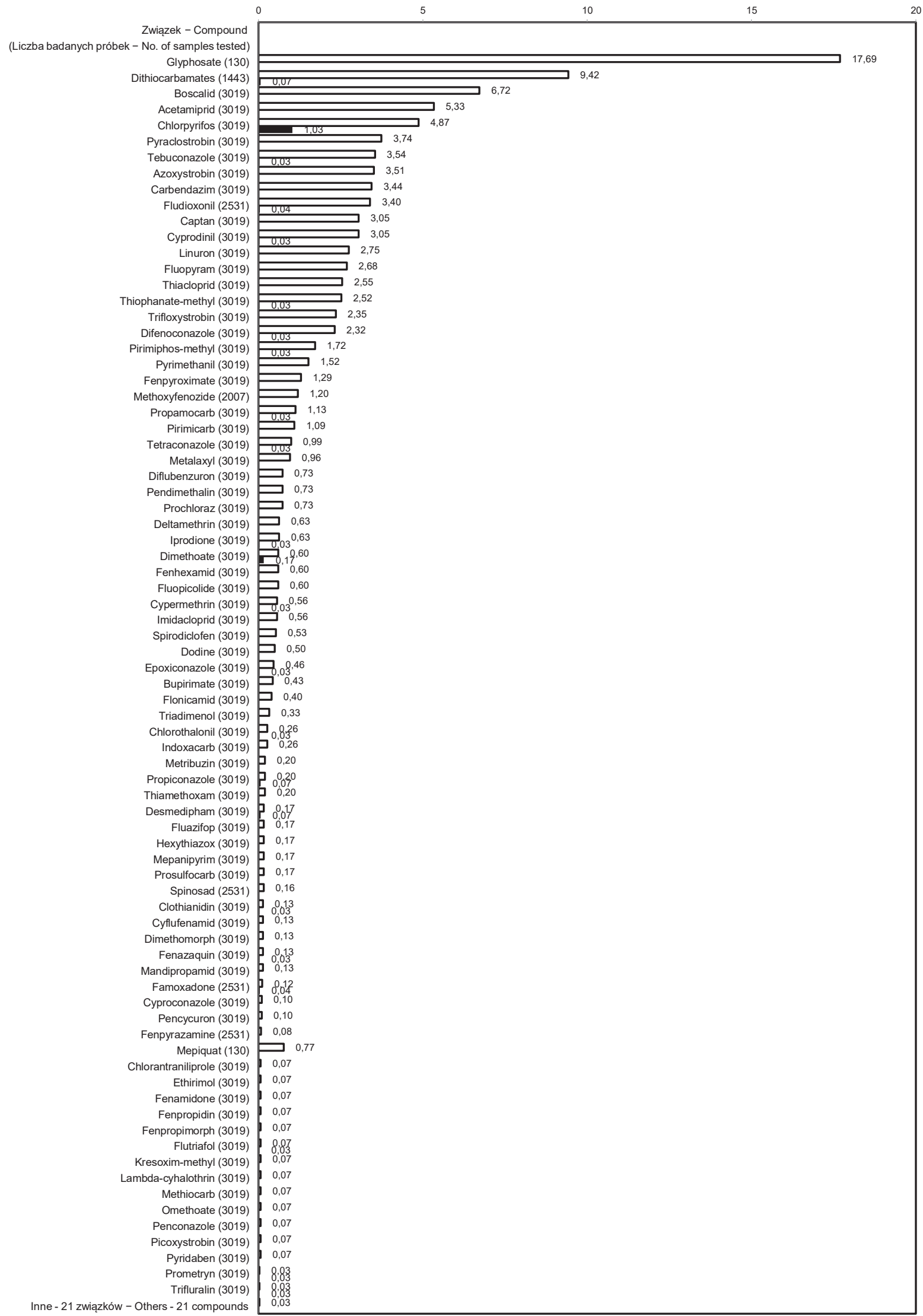

口Próbki z pozostałościami - Samples with residues

- Próbki z pozostałościami > NDP - Samples with residues > MRLs

Rys. 4. Częstotliwość wykrywania poszczególnych związków (2016-2017)

Fig. 4. Frequency of occurrence of the compounds detected (2016-2017) 
gólności zawierających chloropiryfos $(0,9 \%)$. Z dniem 10 sierpnia 2016 r. drastycznie obniżono najwyższe dopuszczalne poziomy pozostałości chloropiryfosu w wielu produktach roślinnych (Rozporządzenie 2016) w stosunku do wcześniej obowiązujących (Rozporządzenie 2008), m.in. w jabłkach, gruszkach, malinach, papryce, kapuście pekińskiej z 0,5 mg/kg do $0,01 \mathrm{mg} / \mathrm{kg}$, a w porzeczkach $\mathrm{z} 1,0 \mathrm{mg} / \mathrm{kg}$ do $0,01 \mathrm{mg} / \mathrm{kg}$. Dopasownie do nowych wymogów w zakresie NDP spowodowało zmiany zakresów stosowania preparatów zawierających chloropiryfos (Wykaz 2020), określone w załącznikach do decyzji MRiRW zmieniających pozwolenia dla środków, takich jak: Chlorop - Pro 480 EC (decyzja MRiRW nr R-328/2016d), Cyperpirifos 550 EC (decyzja MRiRW nr R-317/2016d), Cyren 480 EC (decyzja MRiRW nr R-540/2017d), Dursban 480 EC (decyzje MRiRW nr R-167/2016d i nr R-116/2017d), Dursban Delta 200 CS (decyzja MRiRW nr R-329/2016d), Klon 480 EC (decyzja MRiRW nr R-282/2016d), Klon Max 550 EC (decyzja MRiRW nr R-315/2016d), Klon 48 EC (decyzja MRiRW nr R-276/2016d), Nurelle D 550 EC (decyzja MRiRW nr R-46/2017d), Owadofos Extra 480 EC (decyzja MRiRW nr R-275/2016d), Pyrinex Supreme 262 ZW (decyzja MRiRW nr R-314/2016d), Pyrisimex 480 EC (decyzja MRiRW nr R-313/2016d), Rook 480 EC (decyzja MRiRW nr R-327/2016d), Troll 550 EC (decyzja MRiRW nr R-319/2016d). Nowelizacja przepisów wpłynęła na wzrost przekroczeń NDP w krajowych płodach rolnych w latach 2016-2017 w porównaniu z latami poprzednimi (Nowacka i wsp. 2020). Identyczne zjawisko zaobserwowano w całej Unii Europejskiej. W raporcie z monitoringów przeprowadzonych w krajach członkowskich w 2016 roku odnotowano ścisłą korelację wzrostu odsetka przekroczeń NDP z obniżeniem norm dla pozostałości chloropiryfosu (Scientific Report 2018). NDP dla chloropiryfosu zmniejszono do poziomu $0,01 \mathrm{mg} / \mathrm{kg}$ dla kolejnych produktów w 2018 roku, m.in. dla większości warzyw korzeniowych (Rozporządzenie 2018). W dniu 6 grudnia 2019 r. Stały Komitet ds. Roślin, Zwierząt, Żywności i Pasz wydał decyzję o nieprzedłużeniu zatwierdzenia chloropiryfosu jako substancji czynnej zgodnie z rozporządzeniem (WE) nr 1107/2009, z uwagi na możliwe działanie genotoksyczne, w tym niepożądane działanie neurologiczne u dzieci (Final Report 2019), zasygnalizowane przez Europejski Urząd ds. Bezpieczeństwa Żywności (Statement 2019). Ogólnounijny zakaz stosowania tej substancji owadobójczej obowiązuje od dnia 16 kwietnia 2020 r. (Rozporządzenie 2020). W związku z tym, w najbliższej przyszłości najwyższy dopuszczalny poziom pozostałości chloropiryfosuwe wszystkich produktach roślinnych będzie stanowił 0,01 mg/ $\mathrm{kg}$, co może spowodować wzrost naruszeń NDP w żywności w nadchodzących latach.

Badania ujawniły obecność niedozwolonych substancji czynnych ś.o.r. w próbkach warzyw (13,3\%), owoców $(8,1 \%)$, ziarna zbóż $(0,8 \%)$, nasion oleistych $(0,7 \%)$ i strączkowych $(3,4 \%)$ oraz w przyprawach $(77,8 \%)$, łącznie w 273 badanych próbkach (9,0\%). Nieprawidłowości dotyczyły 72 związków i 41 spośród 60 badanych gatunków roślin uprawnych (tab. 3, rys. 5). Wysoki, ponad 50-procentowy odsetek próbek z pozostałościami substancji niedopuszczonych do ochrony stwierdzono w przypadku jarmużu (100,0\%), kminku (77,8\%) i kopru $(71,4 \%)$, niższy, ale znaczący dla kapusty pekińskiej $(48,4 \%)$, moreli $(44,4 \%)$, agrestu $(34,2 \%)$, brzoskwiń $(31,6 \%)$, porzeczek (29,3\%), selera korzeniowego (29,2\%), marchwi (29,0\%), pasternaku (26,7\%), winogron $(25,5 \%)$ i sałaty $(25,0 \%)$. W przypadku 28 gatunków upraw naruszenia nie przekraczały $25,0 \%$, przy czym dla $11 \mathrm{z}$ nich stanowiły od $0,8-5,0 \%$. Najwięcej niedozwolonych związków wykryto w próbkach kopru, kapusty pekińskiej, porzeczek i sałaty, odpowiednio - 16, 14, 13 i 13. Niezalecane stosowanie chloropiryfosu wychwycono w 116 badanych próbkach $(3,8 \%)$ pochodzących z 26 gatunków upraw.

Nasilenie problemu polegającego na używaniu środków niedopuszczonych do ochrony upraw zaobserwowano po zakończeniu wieloletniego procesu oceny substancji czynnych w Unii Europejskiej, skutkującego wycofaniem z rynku unijnego kilkuset $\mathrm{z}$ nich. Wraz z wprowadzeniem rozporządzenia (WE) nr 1107/2009 i wykazu zatwierdzonych substancji czynnych (Rozporządzenie 2011b) skurczył się asortyment substancji czynnych dostępnych do ochrony upraw małoobszarowych. Wieloletnie badania prowadzone przez IOR - PIB pokazują, że producenci niejednokrotnie sięgają po środki niedozwolone chroniąc uprawy warzywnicze, sadownicze i zielarskie. W okresie 2012-2017, systematycznie rósł ogólny procent przypadków wykrywania preparatów niedozwolonych. W 2012 roku wynosił jedynie 2,2\% (Nowacka i wsp. 2014), w 2013 roku stanowił już 6,5\% (Nowacka i wsp. 2015), w latach 2014-2015 zwiększył się do 8,5\% (Nowacka i wsp. 2020) i osiągnął poziom 9,0\% w latach 2016-2017. W grupie warzyw odsetek naruszeń utrzymywał się na bardzo zbliżonym poziomie w latach 2014-2015 i 2016-2017, stanowiącym 13,5\% i 13,3\%, natomiast $\mathrm{w}$ grupie owoców nastąpił ich spadek z 10,0\% w latach 2014-2015 do 8,1\% w latach 2016-2017 (Nowacka i wsp. 2020).

Wyniki przeprowadzonych badań w latach 2016-2017 wskazują, że ogólny odsetek wykryć pozostałości i przekroczeń NDP (38,2\% i 1,9\%) w porównaniu z latami 20142015 wzrósł, gdyż wówczas wynosił odpowiednio - 27,5\% i 1,4\% (Nowacka i wsp. 2020). Dla owoców oraz warzyw stwierdzono taki sam trend w wykrywaniu pozostałości i przekroczeń NDP, w latach 2016-2017 stanowiły one odpowiednio: $55,8 \%$ i $1,7 \%$ oraz $33,5 \%$ i $2,7 \%$, natomiast w latach 2014-2015 kształtowały się na poziomie 45,4\% i 1,1\% oraz 27,1\% i 2,3\% (Nowacka i wsp. 2020).

Porównując przedstawione wyniki badań z wynikami badań monitoringowych żywności prowadzonych w krajach członkowskich Unii Europejskiej (UE) i w Stanach 
Procent próbek - Percentage of samples z substancjami niedozwolonymi; Niedozwolone substancje Samples tested / with non-approved substances; Non-approved substances

Agrest - Gooseberries $(38 / 13 ; 9)$

Brzoskwinie - Peaches (19/6; 4$)$

Czereśnie - Sweet cherries $(38 / 9 ; 8)$

Gruszki - Pears $(70 / 7 ; 6)$

Jabłka - Apples $(209 / 4 ; 4)$

Maliny - Raspberries $(131 / 3 ; 2)$

Morele - Apricots $(9 / 4 ; 3)$

Porzeczki - Currants $(123 / 36 ; 14)$

Śliwki - Plums $(78 / 10 ; 7)$

Truskawki - Strawberries $(139 / 3 ; 3)$

Winogrona - Grapes $(55 / 14 ; 7)$

Wiśnie - Sour cherries $(71 / 1 ; 1)$

Bób - Broad bean $(20 / 1 ; 1)$

Brokuły - Broccoli (61/2; 2$)$

Cebula siedmiolatka - Green onions $(14 / 2 ; 2)$

Chrzan - Horseradishes $(26 / 2 ; 1)$

Jarmuż - Kales $(8 / 8 ; 7)$

Kapusta pekińska - Chinese cabbage $(93 / 45 ; 14)$

Koper - Dill $(63 / 45 ; 17)$

Marchew - Carrots $(69 / 20 ; 1)$

Ogórki - Cucumbers $(54 / 9 ; 6)$

Papryka - Sweet pepper $(30 / 2 ; 2)$

Pasternak - Parsnips $(15 / 4 ; 4)$

Pieczarki - Mushrooms $(70 / 5 ; 1)$

Pietruszka (korzeń) - Parsley (root) $(69 / 16 ; 7)$

Pomidory - Tomatoes $(137 / 15 ; 6)$

Por - Leek $(80 / 3 ; 2)$

Rukola - Rucola (13/2; 1$)$

Rzodkiewka - Radish $(46 / 8 ; 6)$

Sałata - Lettuce $(76 / 19 ; 13)$

Seler korzeniowy - Celeriac $(72 / 21 ; 8)$

Szczypiorek - Chives $(18 / 4 ; 4)$

Szparagi - Asparagus $(5 / 1 ; 1)$

Szpinak - Spinaches $(42 / 6 ; 5)$

Fasola - Bean $(32 / 1 ; 1)$

Groch - Pea $(26 / 1 ; 1)$

3,1

Rzepak - Rapeseed (130/1; 1) ] 0,8

Gryka - Buckwheat (21/3; 3) 14,3

Proso - Common millet $(9 / 1 ; 1) \longrightarrow 11,1$

Pszenżyto - Triticale $(89 / 1 ; 1) \quad 1,1$

Kminek - Black caraway $(9 / 7 ; 5)$

Ogółem - Overall (3019/273; 72

Owoce - Fruits $(1005 / 81 ; 41)$

Warzywa - Vegetables $(1348 / 179 ; 49)$

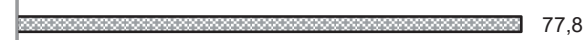

Nasiona roślin strączkowych - Pulses $(58 / 2 ; 2) \quad 3,4$

Nasiona oleiste - Oil seeds $(140 / 1 ; 1), 0,7$

Zboża - Cereals $(397 / 3 ; 5)$ ] 0,8

Przyprawy - Spices $(9 / 7 ; 5)$

77,8

Rys. 5. Odsetek produktów z pozostałościami środków niedopuszczonych (2016-2017)

Fig. 5. Percentage of products with residues of unauthorised plant protection products (2016-2017) 
Zjednoczonych (USA) można wnioskować, że skala skażenia krajowych płodów rolnych pozostałościami ś.o.r. jest zbliżona do obserwowanej w UE i USA. Statystyki z badań żywności, opracowane przez Europejski Urząd ds. Bezpieczeństwa Żywności (EFSA), przeprowadzonych $\mathrm{w}$ ramach skoordynowanego monitoringu UE i monitoringów krajowych państw członkowskich pokazują, że odsetki próbek żywności bez pozostałości ś.o.r. stanowiły w roku 2016 i 2017 odpowiednio 50,7\% i 54,1\%, natomiast procent próbek niezgodnych z wymaganiami, czyli z przekroczeniami NDP uwzględniającymi niepewność pomiaru, wynosił w 2016 roku - 2,2\%, a w roku $2017-2,5 \%$ (Scientific Report 2018, 2019). Raporty z monitoringu pozostałości ś.o.r. publikowane przez Amerykańską Agencję Żywności i Leków (FDA) podają wskaźniki przekroczeń tolerancji dla żywności wyprodukowanej w USA w roku 2016 i 2017 na poziomie - 0,9\% i 3,8\%, a odsetek żywności niezawierającej pozostałości ś.o.r. jako stanowiący - 52,9\% i 52,5\% (Pesticide 2018, 2019). Procent próbek owoców, warzyw i zbóż z przekroczeniami tolerancji w 2016 oraz 2017 roku wynosił dla produkcji amerykańskiej odpowiednio - 1,2\%, 3,0\%, 0,1\% oraz 1,8\%, 9,4\%, 1,6\% (Pesticide 2018, 2019).

Urzędowa kontrola pozostałości ś.o.r. prowadzona na etapie produkcji pierwotnej w latach 2016-2017 obejmowała szeroki wachlarz krajowych płodów rolnych oraz substancji czynnych ś.o.r. i była ukierunkowana na obszary potencjalnych zagrożeń. Kontrola pozwoliła na identyfikowanie nieprawidłowości w stosowaniu ochrony roślin i uruchamianie działań zmierzających do ich ograniczania, poprzez edukację producentów i nakładanie kar. Najwięcej zdiagnozowanych zagrożeń wiązało się ze stosowaniem środków niedopuszczonych do ochrony roślin małoobszarowych. Dotychczasowe działania mające na celu ograniczenie tego niekorzystnego zjawiska, polegające na rozszerzaniu rejestracji na zastosowania małoobszarowe są powolne, a tym samym mało skuteczne. W najbliższych miesiącach i latach planowane jest wycofanie wielu kluczowych substancji czynnych z ochrony roślin w UE. Cięcia te przy słabej alternatywie w postaci substancji nowej generacji wpłyną najprawdopodobniej na wzrost nieprawidłowości w stosowaniu środków, nie tylko w uprawach małoobszarowych. Częste zmiany przepisów w zakresie stosowania środków wymagają od producentów szybkiego reagowania na wprowadzane zmiany w celu sprostania nowym wymogom. Z badań wynika, że proces dostosowywania się do zmienionych regulacji nie jest łatwy i przebiega znacznie dłużej niż to zakładają przepisy.

\section{Wnioski / Conclusions}

1. W $61,8 \%$ badanych próbek nie wykryto pozostałości ś.o.r.
2. Pozostałości ś.o.r. stwierdzono w 38,2\% badanych próbek płodów rolnych, głównie w owocach $(55,8 \%)$ i przyprawach (77,8\%), rzadziej w warzywach $(33,5 \%)$, nasionach roślin oleistych $(39,3 \%)$ i strączkowych $(6,9 \%)$, roślinach cukrodajnych $(25,8 \%)$ oraz w ziarnie zbóż (14,9\%).

3. Próbki z jedną pozostałością stanowiły $18,1 \%$ ogółu badanych, a z wieloma pozostałościami - 20,1\%, w tym przeważnie z dwoma $(8,1 \%)$ i trzema $(5,9 \%)$.

4. Ogółem wykryto 99 spośród 499 badanych substancji czynnych ś.o.r., w tym fungicydów - 50, insektycydów i akarycydów - 32 oraz herbicydów i regulatorów wzrostu -17 .

5. Obecność pozostałości środków niedopuszczonych do stosowania stwierdzono w 9,0\% badanych próbek, sporadycznie występowały w ziarnie zbóż $(0,8 \%)$, nasionach roślin oleistych $(0,7 \%)$ i strączkowych $(3,4 \%)$, częściej w warzywach $(13,3 \%)$, owocach $(8,1 \%)$ i przyprawach $(77,8 \%)$, co było konsekwencją niewystarczającego asortymentu środków do ochrony roślin małoobszarowych.

6. Ogólny odsetek próbek niezgodnych z wymaganiami, zawierających przekroczenia NDP uwzględniające 50-procentową niepewność pomiaru, wynosił 1,9\%. Naruszenia najwyższych dopuszczalnych poziomów były w dużym stopniu związane z niedozwolonym stosowaniem chloropiryfosu (0,9\%). Przekroczenia NDP odnotowano w 11,1\% próbek przypraw, 2,7\% próbek warzyw, $1,7 \%$ próbek owoców oraz w $0,7 \%$ próbek nasion oleistych.

7. Wyniki badań potwierdzają konieczność i skuteczność prowadzenia nadzoru nad prawidłowością stosowania środków ochrony roślin oraz ich znaczenie w identyfikowaniu pojawiających się zagrożeń w tym zakresie.

\section{Podziękowanie / Acknowledgements}

Wyrazy podziękowania dla pracowników IOR - PIB uczestniczących w badaniach pozostałości ś.o.r. w latach 20162017 realizowanych w ramach programu wieloletniego na lata 2016-2020 pn. ,Ochrona roślin uprawnych z uwzględnieniem bezpieczeństwa żywności oraz ograniczenia strat w plonach i zagrożeń dla zdrowia ludzi, zwierząt domowych i środowiska": Bogusława Gnusowskiego, Dariusza Drożdżyńskiego, Michała Raczkowskiego, Moniki Przewoźniak, Marty Zdziechowskiej, Andrzeja Ziółkowskiego, Anny Wesołowskiej, Urszuli Zeller, Alicji Małeckiej, Urszuli Rzeszutko, Klaudii Pszczolińskiej, Izabeli Domańskiej, Sabiny Newelt, Justyny Cieszowic, Bożeny Łozowickiej, Piotra Kaczyńskiego, Ewy Rutkowskiej, Izabeli Hrynko, Patrycji Mojsak, Julii Rusiłowskiej. 


\section{Literatura / References}

Anastassiades M., Lehotay S.J., Stajnbaher D., Schenck F.J. 2003. Fast and easy multiresidue method employing acetonitrile extraction/ partitioning and "dispersive solid-phase extraction" for the determination of pesticide residues in produce. Journal of AOAC International 86 (2): 412-431. DOI: 10.1093/jaoac/86.2.412

Chmiel Z. 1979. Spektrofotometryczne oznaczanie śladowych pozostałości dwutiokarbaminianów w materiale roślinnym. Chemia Analityczna 24: 505-511.

Dyrektywa Parlamentu Europejskiego i Rady 2009/128/WE z dnia 21 października 2009 r. ustanawiająca ramy wspólnotowego działania na rzecz zrównoważonego stosowania pestycydów 2009. Dz. Urz. L 309, z 24.11.2009 r., str. 71.

Final Renewal report for the active substance chlorpyrifos finalised in the Standing Committee on Plants, Animals, Food and Feed at its meeting on 6 December 2019 in view of the non-renewal of the approval of chlorpyrifos as an active substance in accordance with Regulation (EC) No 1107/20091. 2019. Chlorpyrifos - SANTE/11938/2019 Rev 16 December 2019.

Guidance document on analytical quality control and method validation procedures for pesticides residues analysis in food and feed. Document no. SANTE/11945/2015. Supersedes Document No. SANCO/12571/2013. Implemented by 01/01/2016. 2015.

Norma PN-EN 15662:2008. 2008. Żywność pochodzenia roślinnego - Oznaczanie pozostałości pestycydów metodą GC-MS i/lub LC-MS/ MS) po uprzedniej ekstrakcji i rozdziale acetonitrylem oraz oczyszczaniu metodą dyspersyjnej SPE - Metoda QuEChERS.

Norma PN-EN ISO/IEC 17025:2005. 2005. Ogólne wymagania dotyczące kompetencji laboratoriów badawczych i wzorcujących.

Nowacka A., Gnusowski B., Walorczyk S., Drożdżyński D., Raczkowski M., Hołodyńska-Kulas A., Frąckowiak D., Wójcik A., Ziółkowski A., Przewoźniak M., Swoboda W., Rzeszutko U., Domańska I., Pszczolińska K., Łozowicka B., Kaczyński P., Rutkowska E., Jankowska M., Hrynko I., Szpyrka E., Rupar J., Rogozińska K., Kurdziel A., Słowik-Borowiec M., Szala J., Szponik M. 2014. Pozostałości środków ochrony roślin w płodach rolnych (rok 2012). [Pesticide residues in agricultural crops (2012)]. Progress in Plant Protection 54 (2): 219-230. DOI: 10.14199/ppp-2014-035

Nowacka A., Gnusowski B., Walorczyk S., Drożdżyński D., Raczkowski M., Hołodyńska-Kulas A., Frąckowiak D., Ziółkowski A., Przewoźniak M., Rzeszutko U., Domańska I., Pszczolińska K., Łozowicka B., Kaczyński P., Rutkowska E., Jankowska M., Hrynko I., Szpyrka E., Rupar J., Matyaszek A., Kurdziel A., Podbielska M., Słowik-Borowiec M., Szponik M. 2015. Pozostałości środków ochrony roślin w płodach rolnych (rok 2013). [Pesticide residues in agricultural crops (2013)]. Progress in Plant Protection 55 (4): 423-439. DOI: 10.14199/ppp-2015-071.

Nowacka A., Hołodyńska-Kulas A., Drożdżyński D., Przewoźniak M., Pszczolińska K., Łozowicka B., Kaczyński P. 2020. Pozostałości środków ochrony roślin w płodach rolnych (2014-2015). [Pesticide residues in agricultural crops (2014-2015)]. Progress in Plant Protection 60 (2): 81-104. DOI: 10.14199/ppp-2020-010

Pesticide Residue Monitoring Program Fiscal Year 2016 Pesticide Report. U.S. Food and Drug Administration. 2018. https://www.fda. gov/media/117088/download [dostęp: 15.06.2020].

Pesticide Residue Monitoring Program Fiscal Year 2017 Pesticide Report. U.S. Food and Drug Administration. 2019. https://www.fda. gov/media/130291/download [dostęp: 15.06.2020].

Rozporządzenie (WE) nr 178/2002 Parlamentu Europejskiego i Rady z dnia 28 stycznia 2002 r. ustanawiające ogólne zasady i wymagania prawa żywnościowego, powołujące Europejski Urząd ds. Bezpieczeństwa Żywności oraz ustanawiające procedury w zakresie bezpieczeństwa żywności. 2002. Dz. Urz. UE L 31, str. 1 z dnia 01.02.2002 r. z późn. zm.; polskie wydanie specjalne: rozdz. 15, t. 6, str. 463.

Rozporządzenie (WE) nr 396/2005 Parlamentu Europejskiego i Rady z dnia 23 lutego 2005 r. w sprawie najwyższych dopuszczalnych poziomów pozostałości pestycydów w żywności i paszy pochodzenia roślinnego i zwierzęcego oraz na ich powierzchni, zmieniające dyrektywę Rady 91/414/EWG. 2005. Dz. Urz. UE L 70 z 16.03.2005 r., str. 1-16.

Rozporządzenie Komisji (WE) nr 839/2008 z dnia 31 lipca 2008 r. zmieniające rozporządzenie (WE) nr 396/2005 Parlamentu Europejskiego i Rady w odniesieniu do załączników II, III i IV dotyczących najwyższych dopuszczalnych poziomów pozostałości pestycydów w określonych produktach oraz na ich powierzchni. 2008. Dz. Urz. UE L 234 z 30.08.2008 r., str. 1-216.

Rozporządzenie Komisji (UE) nr 16/2011 z dnia 10 stycznia 2011 r. ustanawiające środki wykonawcze dla systemu wczesnego ostrzegania o niebezpiecznych produktach żywnościowych i środkach żywienia zwierząt. 2011a. Dz. Urz. UE L 6 z 10.01.2011 r., str. 7.

Rozporządzenie Komisji (UE) 2016/60 z dnia 19 stycznia 2016 r. zmieniające załączniki II i III do rozporządzenia (WE) nr 396/2005 Parlamentu Europejskiego i Rady w odniesieniu do najwyższych dopuszczalnych poziomów pozostałości chloropiryfosu w określonych produktach oraz na ich powierzchni. 2016. Dz. Urz. UE L 14 z 21.01.2016 r., str. 1-17.

Rozporządzenie Komisji (UE) 2018/686 z dnia 4 maja 2018 r. zmieniające załączniki II i III do rozporządzenia (WE) nr 396/2005 Parlamentu Europejskiego i Rady w odniesieniu do najwyższych dopuszczalnych poziomów pozostałości chloropiryfosu, chloropiryfosu metylowego i triklopyru w określonych produktach lub na ich powierzchni. 2018. Dz. Urz. UE L 121 z 16.05.2018 r., str. 30-62.

Rozporządzenie Ministra Rolnictwa i Rozwoju Wsi z dnia 27 listopada 2013 r. w sprawie pobierania próbek roślin, produktów roślinnych lub przedmiotów do badań na obecność pozostałości środków ochrony roślin. 2013. Dz. U. z 2013 r., poz. 154.

Rozporządzenie Parlamentu Europejskiego i Rady (WE) nr 1107/2009 z dnia 21 października 2009 r. dotyczące wprowadzania do obrotu środków ochrony roślin i uchylające dyrektywy Rady 79/117/EWG i 91/414/EWG. 2009. Dz. Urz. UE L 309 z 24.11.2009 r., str. $1-50$

Rozporządzenie Wykonawcze Komisji (UE) 540/2011 z dnia 25 maja 2011 r. w sprawie wykonania rozporządzenia Parlamentu Europejskiego i Rady (WE) nr 1107/2009 w odniesieniu do wykazu zatwierdzonych substancji czynnych. 2011b. Dz. Urz. UE L 153 z 11.06.2011 r., str. $1-186$

Rozporządzenie Wykonawcze Komisji (UE) 2020/18 z dnia 10 stycznia 2020 r. w sprawie nieodnowienia zatwierdzenia substancji czynnej chloropiryfos, zgodnie z rozporządzeniem Parlamentu Europejskiego i Rady (WE) nr 1107/2009 dotyczącym wprowadzania do obrotu środków ochrony roślin, oraz w sprawie zmiany załącznika do rozporządzenia wykonawczego Komisji (UE) $\mathrm{nr}$ 540/2011. 2020. Dz. Urz. UE L 7 z 13.01.2020 r., str. 14-16.

Scientific Report of EFSA. 2018. The 2016 European Union report on pesticide residues in food. EFSA Journal 2018 ; 16 (7): 5348 , 139 ss. DOI: $10.2903 /$ j.efsa.2018.5348

Scientific Report of EFSA. 2019. The 2017 European Union report on pesticide residues in food. EFSA Journal $2019 ; 17$ (6): 5743 , 152 ss. DOI: $10.2903 /$ j.efsa.2019.5743

Statement on the available outcomes of the human health assessment in the context of the pesticides peer review of the active substance chlorpyrifos. 2019. EFSA Journal 2019; 17 (5): 5809. DOI: 10.2903/j.efsa.2019.5809 
Uchwała nr 225/2015 Rady Ministrów z dnia 15 grudnia 2015 r. w sprawie ustanowienia programu wieloletniego pod nazwą „Ochrona roślin uprawnych z uwzględnieniem bezpieczeństwa żywności oraz ograniczenia strat w plonach i zagrożeń dla zdrowia ludzi, zwierząt domowych i środowiska". 2015.

Ustawa z dnia 18 grudnia 2003 r. o ochronie roślin. 2004. Dz. U. 2004 nr 11, poz. 95 z późn. zm.; tekst jednolity z dnia 15.01.2014 r.

Ustawa z dnia 25 sierpnia 2006 r. o bezpieczeństwie żywności i żywienia. 2010. Dz. U. 2010 nr 136, poz. 914, z późn. zm.

Ustawa z dnia z 8 marca 2013 r. o środkach ochrony roślin. 2013. Dz. U. z 2013, poz. 455.

Walorczyk S. 2008. Development of a multi-residue method for the determination of pesticides in cereals and dry animal feed using gas chromatography-tandem quadrupole mass spectrometry II. Improvement and extension to new analytes. Journal of Chromatography A 1208 (1-2): 202-214. DOI: 10.1016/j.chroma.2008.08.068

Walorczyk S., Drożdżyński D. 2011. Development and validation of a routine multiresidue method for determining 140 pesticides in fruits and vegetables by gas chromatography/tandem quadrupole mass spectrometry. Journal of AOAC International 94 (5): $1625-1642$. DOI: $10.5740 /$ jaoacint.10-329

Wykaz zezwoleń i decyzji zmieniających. Rejestr Środków Ochrony Roślin. Ministerstwo Rolnictwa i Rozwoju Wsi. 2020. https://www. gov.pl/attachment/345067ad-d4a9-4124-8581-54109fda054c [dostęp: 04.08.2020]. 